\title{
Fotograf fra Stanko Dujmović (1866. - 1940.)
}

\begin{abstract}
Stanko Dujmović (1866. - 1940.), franjevac trećoredac, fotografijom se počeo baviti tijekom školovanja u Zadru. Brzo je savladao tehniku mokrih kolodijskih ploča i u izradi portreta dostignuo kvalitetu tadašnjih profesionalnih fotografa. Vršio je neke od najviših dužnosti u Provinciji i Redu. Od 1907. do 1911. u Spaldingu (Nebraska) podignuo je Spalding College za obrazovanje mladih svećenika i radio na organiziranju Reda. Iz tog perioda sačuvao se album s autoriziranim fotografijama veduta, ambijentalnih pojedinačnih i grupnih portreta i žanr-prizora te memoarskim zapisom. Fotografije iz tog razdoblja karakterizira spoj umjerenog piktorijalizma, naturalističke fotografije P. H. Emersona i onoga što će Lewis Hine imenovati interpretativnom fotografijom. Stilska konzistentnost i raznolikost tema koje odlikuju spaldinški album više se neće ponoviti. Ubuduće gotovo isključivo izrađuje portrete i autoportrete. Snima subraću, suradnike, prijatelje i njihove obitelji u domovini i SAD-u, koje posjećuje u još dvama navratima. U posljednjoj fazi opredjeljuje se za čistu fotografiju. Niz nepretencioznih portreta malih formata krasi neposredan pristup, jednostavnost i autentična emocija. Zbog zasluga u osnivanju prve Provincije franjevaca trećoredaca u SAD-u, danas Provincije Presvetog Srca Isusova, njegovi zemni ostaci bit će preneseni u Loretto (Pensilvanija).
\end{abstract}

Među izlošcima u muzeju samostana u Portu ${ }^{1}$ ističe se drvena, trošna kutija na vitkom, također drvenom tronošcu. Radi se o antiknoj fotografskoj kameri na mijeh, proizvedenoj u drugoj polovini 19. stoljeća. S obziromna to da na tijelu kamere, kako na drvenim, tako i na njenim metalnim dijelovima, nema nikakvih oznaka, a nedostaje i objektiv, bez stručne ekspertize i temeljitog istraživanja nije moguće utvrditi njezino podrijetlo i precizniju dataciju. Ta je kamera pripadala fratru trećorecu, fotografu Stanku Dujmoviću. Postavljena je u odjel s knjigama, raznim pisaćim priborom i sličnom opremom kao prikladna ilustracija širokog spektra interesa franjevaca intelektualaca s konca 18., 19. i početka 20. stoljeća,

* Fra Stanko Dujmović spominje se u sljedećim stručnim radovima posvećenim fotografskim temama: N. GRČEVIĆ 1977; Ista 1981; SEFEROVIĆ 1993; TONKOVIĆ 1994; DUBROVIĆ 1995; SMOKVINA 2001; SEFEROVIĆ 2009; SMOKVINA 2015.

1 Autor je postava ovog muzeja, u čast petstogodišnjici samostana u Portu, fra Anđelko Badurina, TOR. U Portu se čuva dio i njegove fotografske ostavštine, koja također zaslužuje stručnu reviziju i valorizaciju. 
kakav je bio i sam Stanko Dujmović². Uz ovu, znamo za još dvije kamere kojima se vjerojatno služio fra Stanko. Obje se čuvaju u samostanu sv. Franje u Krku. Radi se o drvenoj kameri bez stalka, tzv. reisekameri poznatog bečkog proizvođača R. A. Goldmanna s prijelaza stoljeća te Agfinoj Billy Rekord kameri. Dujmovićevu fotografsku ostavštinu čini petstotinjak fotografija razvrstanih u osam albuma, tek nekoliko fotografija izvan albuma koje mu sa sigurnošću pripisujemo te neizvjestan, manji broj negativa u samostanima u Portu, Krku i Zagrebu.

Stanko Dujmović rođen je u Portu na otoku Krku 27. siječnja 1866., u obitelji s nadimkom Paronovi ${ }^{3}$. S deset godina dolazi u glavotočki samostan kao kandidat, gdje završava tri razreda niže gimnazije. Četvrti razred niže i višu gimnaziju pohađao je u Zmajevićevu sjemeništu u Zadru, gdje prima i habit. Bogoslovno sjemenište u Zadru pohađa 1884. - 1888., a Bogoslovno sveučilište u Rimu (Gregoriana) 1890. - 1893., gdje doktorira 1903. Dvije godine, od konca 1888. do konca 1890., lektor je filozofije u krčkoj školi, a taj posao, kao i dužnosti gvardijana više samostana, obavljao je i nakon završetka studija. Godine 1904. odlazi u Rim na dužnost generalnog definitora Reda, koju obavlja do 1920. Kao povjerenik generalne kurije, 1907. - 1911. boravi u SAD-u, u malom mjestu Spalding u Nebraski, sa zadatkom organiziranja nove zajednice trećoredaca, prve na ovom kontinentu. To je bio tek prvi od triju radnih posjeta SAD-u. Drugi je put na nekoliko mjeseci 1913. mijenjao prijatelja, župnika u Johnstownu u Pensilvaniji, a treći put je, već kao šezdesetogodišnjak, od 1926. do 1931. poslan da financijski pomogne posustalu provinciju u domovini. Posljednje godine života uglavnom provodi u Herceg Novom.

2 Čak i samo letimični pogled na njegovu biografiju otkriva osebujnu ličnost. Doktorirao na Papinskom sveučilištu Gregoriana u Rimu, gdje kao alumni obavlja dužnost generalnog podtajnika 1890. - 1893., tijekom služenja obnašao je neke od najviših funkcija u hijerarhiji Provincije i Reda; kao poliglot i vješt organizator, u trima je navratima boravio u SAD-u na uspostavljanju nove redovničke zajednice i prikupljanju sredstava za materijalno posustalu Provinciju (,Jedan moj genijalni prijatelj nazvao me Il Padre Stanislao, Cristoforo Colombo del Terzo Ordine jer sam prvi pošao u Ameriku i otkrio novi svijet svojoj braći trećoredcima, veliko polje za apostol među našom iseljeničkom braćom...") - Provincija Franjevaca trećoredaca glagoljaša, Zagreb, Ostavština fra Stanka Dujmovića, svezak IV. (f. 14v); aktivno je sudjelovao u izgradnji i obnovi više crkava i samostana, uključujući i kompleks Provincije na Ksaveru u Zagrebu... Najbolji prilog za svoju biografiju dao je sam Stanko Dujmović vlastitim rukopisnim memoarskim zapisima, pohranjenima u arhivu Provincije franjevaca trećoredaca glagoljaša u Zagrebu. (Od četiriju bilježnica manjeg formata, osobno sam imao uvid u treći i četvrti svezak). Ovim izvorima koristio se Nikola Gregov u biografskim člancima posvećenima fra Stanku Dujmoviću: GREGOV 1965: 37-40; Isti 1965b, 66-73. Prema Gregovljevu tekstu, biografske podatke navodili su ostali autori koji su pisali o fra Stanku Dujmoviću: N. GRČEVIĆ 1977; N. GRČEVIĆ 1981; SEFEROVIĆ 2009: 159-160; SMOKVINA 2015: 7-31.

3 Krsna imena zapravo su mu Ivan - Napoleon. Na dan zaređenja u samostanu sv. Mihovila u Zadru, 28. listopada 1882., prima ime Stanislav. 
Premda u Glavotok, gdje biva pohranjena Parčićeva fotografska oprema, dolazi 1876. i ondje ostaje sljedeće dvije godine, do odlaska na školovanje u zadarsku gimnaziju, presudni susret s Parčićevom ostavštinom dogodit će se tek sedam godina kasnije, tijekom novicijata. Za svladavanje tehnika i vještine izrade fotografija ključne su godine provedene u Zadru, između 1884. i 1888. Tijekom tog razdoblja školovanja u zadarskom Bogoslovnom sjemeništu mladi Stanko Dujmović, kako su već upozorili Nada Grčević i Abdulah Seferovićs ${ }^{4}$, s kolegama Carićem i Jelićem, spoznaje strast prema fotografiji te stječe praktičnu fotografsku naobrazbu i iskustvo. Tako kaže i sam Dujmović: „Jedina moja Ahilova peta bila je fotografija. Moja simpatija za fotografiju počima od rane mladosti od 18 godina; i nikada me nije ostavila; postigao sam lijepih uspjeha..." ${ }^{\text {"6 }}$ Početke i okolnosti bavljenja fotografijom, iskreno i sugestivno, najbolje sažima sam Dujmović u memoarskim zapisima, kojima ćemo se vraćati više puta tijekom ovog izlaganja: „Hercegnovi dne 27 Rujna 1935. Danas sam naumio pisati nešto o jednoj mojoj veoma dvojbenoj vrlini. Znam sa sigurnošću što su drugi mislili osobito moja rodovska braća od ovoj stvari; siguran sam ipak da nisu mogli jako povoljno suditi o stvari, kako ne bih ni ja da su svi oni radili što sam ja radio. Imao sam veliku sklonost za crtanje u opće za grafičke umjetnosti. U školi nismo učili risanje. Kušao sam da sam naučim bez učitelja još za mladih gimnazijalnih dana. Ali sam brzo odustao jer sam vidio da nebude ništa od toga jer je trebalo ustrajnosti, čeza kod mene nije bilo, i djelovalo nepovoljno na moje nejako zdravlje. Išli smo 1883 u novicijat na Glavotok. (...) Tu je bila i stara štamparija i skladište svih stvari negda fratra Kanonika Karla Parčića; bilo je i nekih sprema za fotografiju, posve rudimentalno dakako, jer fotografija bila još in fieri. Ja sam želio nastaviti pokuse prečastnoga Parčića koji je tada bio Kanonik Zavoda Sv. Jerolima u Rimu. Posle novicijata vratismo u Zadar. (...) Ja sam se nesmetano počeo gubiti fotografijom; našao sam prijatelja koji su me podučili i podupirali. Amater fotograf! Velika novost, sviet mi laskao, već početkom godine 1884 imao sam lijepih uspjeha. Premda je još onda bio postupak težak, sredstava malo jer se tražilo plemenite metale zlato i srebro, fiksiralo se strašnim otrovom cijankalijom. Fotografija je napredovala, na štetu škole. Svi profesori prijatelji svetog Mihovila i za milu uspomenu pok. J. Dujmovića (fra Stankov ujak, op. a.) bili su mi pri ruci i zatvarali jedno oko. Dapače, postao sam glasovit: na koncu prve godine prof. Gjivoje ${ }^{7}$ uzima me za

\footnotetext{
N. GRČEVIĆ 1981: 191.

SEFEROVIĆ 2009: 159-160.

6 Provincija Franjevaca trećoredaca glagoljaša, Zagreb, Ostavština fra Stanka Dujmovića, svezak IV. (f. 14v).

Antun Gjivoje (Lastovo, 8. veljače 1851. - Split, 27. travnja 1917.), Hrvatski biografski leksikon, sv. IV, LZMK, Zagreb, 1998.
} 
druga na praznike u Kvarner (u Rijeku, op. a.); na koncu druge godine putujem na Vis i Komižu. Čudovište, mladi fratar fotograf. (...) Tijekom treće godine dolazi iz Rima na vizitaciju Preč o. Emidio Maricotti, negda suučenik sa P. mojim ujcem o. Dujmović na Gregoriani u Rimu, izvrstan redovnik a uz to mekaničar zlatan. I on me zavolio, zamolim ga da se dade fotografirati. Uspjeh je bio sjajan. Svi samostani dobivaju sliku Generalovu od moje ruke. Ja dobivam dozvolu i sredstva da proputujem cijelu redovsku Provinciju, fotografiram crkve i samostane, sve ukupno će biti jedan Spomen Album cijele Provincije. U praznicima godine 1887 dajem se na posao. Sve je išlo dobro dok sam došo u Martinšćicu; tu sam dobio malariju i uzeo sa sobom na Prvić koji je bio zadnji samostan. (...) Gorki istini za ljubav priznati moram da fotografija bila je za mene velika napast i uzrok što sam uložio svoje najbolje darove u nuzgredno, na štetu bogoslovnih znanosti, tu prazninu ja nisam dovoljno dopunio. Ostao sam vjeran svome zvanju radi iskrene ljubavi prema redu, i radi dubokog poštovanja onih dobrih premda kadgod predobrih prema meni, kao o. Jacinto Buić, o. A. Pravdica, o. Benko Zgombić, o. Augustin moj po majki rodjak koji je umro od 26 godina u Martinšćici i razni drugi. I tako svršava prvi period mog fotografičkog života." ${ }^{\text {8 }}$

Da se nikako ne radi o neutemeljenoj samohvali, dokazuje vrsnoća nekoliko sačuvanih portreta iz tog najranijeg perioda. Od spomenutih brojnih umnoženih portreta generalnog ministra E. Maricottija, koji su, po riječima samog Dujmovića, razdijeljeni svim samostanima (vjerojatno misli na samostane unutar Provincije), zasad je poznat tek primjerak $u$ arhivu Provincije. (Slika 1) Radi se o neravnomjerno izrezanom ovalu $(88 \times 79 \mathrm{~mm})$, nemušto zalijepljenom na kartonsku stranicu albuma, s dvama mehaničkim oštećenjima u obliku zarezotina. Nadajmo se da ovo nije zadnji trag i da će se pronaći još koji primjerak, očuvan u punom formatu. Taj rad, kao i dopojasni portreti fra Leonarda, dubašljanskog župnika Ilića ${ }^{9}$ i dubrovačkog klerika Zlovečere (1886.) te učitelja Mahulje (1887. $)^{10}$ kvalitetom nimalo ne zaostaju za radovima iz studija onodobnih profesionalnih fotografa. ${ }^{11}$ Sve radove iz rane faze odlikuje visoka kvaliteta izrade, kako u fazi snimanja, tako i u fazi razvijanja negativa i pozitiva. Osim ponekog izuzetka, radi se o dopojasnim portretima na neutralnoj, sivoj pozadini bez rekvizita. Kasniji radovi iz početne faze, oni iz 90-ih godina 19 . stoljeća, kontrastniji su i oštriji. ${ }^{12}$ Sve su nabrojene

8 Provincija Franjevaca trećoredaca glagoljaša, Zagreb, Ostavština fra Stanka Dujmovića, svezak III. (f. 75r-77r).

$9 \quad$ Ilić (Ilijić), Nikola, dubašljanski župnik 1861. - 1887. BOZANIĆ 2010: 115.

10 Ovdje treba pribrojiti i ženski portret u totalu, kojeg nema u osam navedenih albuma; objavljen u SMOKVINA 2015: 13.

11 SMOKVINA 2015: 13.

12 U ovom nizu nalazi se i portret Ante Starčevića, datiran u 1886. godinu. S obzirom na blijedi otisak i osjetno suženu skalu polutonova u odnosu na ostale radove, radi se o reprodukciji, a ne o originalnoj fotografiji. 
male, kabinet-format fotografije, tzv. dizderijevskog formata (osim portreta o. E. Maricottija, koji je većeg formata) na tankom sjajnom papiru, u tada uobičajenoj tehnici albuminskog otiska. Veći je broj fotografija zalijepljen na crni karton koji na poleđini nosi stilizirani natpis u zlatotisku: Fra Stan. Dujmović, Dilettant-Fotograf. ${ }^{13}$ Jednako je vizualno oblikovana i poleđina kartona znatno većeg formata s portretom umjetnikove majke $(13,5 \times 9 \mathrm{~cm})$, datiranim $1885 .{ }^{14} \mathrm{Karton}$ s portretom župnika Ilića na pozadini nosi izblijedjeli ovalni pečat u zlatotisku s natpisom: FRA STANKO DUJMOVIĆ SVJETLOSLIKAR, jedini takav primjerak i dokaz neposrednog utjecaja Dragutina Parčića, tvorca te kovanice koji se prvi počeo njome koristiti, signirajući vlastite radove. ${ }^{15}$ Posljednji su datirani personalizirani kartoni oni s grupnim portretom kongregacije na Glavotoku 1895. (cca 10 x 14 cm) (Slika 2) i portretom o. Kršića iz 1896. Vjerojatno se radi o iskorištavanju posljednjih zaliha kartona, zaostalih iz vremena školovanja u Zadru jer Dujmović taj period provodi na otoku Krku. Fotografija formata 96 x $141 \mathrm{~mm}$ s prikazom talijanske obitelji (svi prikazani legendirani su u podnožju), aplicirana na karton zasječenih i pozlaćenih bridova, s natpisom Stanko fecit., jedini je očuvani autorizirani karton takvog oblika i posljednji poznat rad na albuminskom papiru, ujedno nagovještaj novog vremena i senzibiliteta. (Slika 3) Izostalo je specifično toniranje u zlatni oker. Pozadina više nije neutralna; naprotiv, obitelj je smještena u realni trodimenzionalni ambijent dvorišta, dočaran cvijećem u vazama i zakošenim kućnim pročeljem sa stubama u lijevom kraju.

Tematski fotografski albumi u to vrijeme nisu rijetkost. Profesionalni zadarski fotografi snimili su ih i objavili već nekoliko. Dujmovićev nesuđeni album, za razliku od uobičajenih, koji su prikazivali probrane motive po izboru autora ili naručioca, izniman je po tome što je zamišljen kao sustavno bilježenje svih samostana provincije, što bi rezultiralo ne samo estetski vrijednom publikacijom, već i sveobuhvatnim katalogom umjetnina jedne redovničke zajednice.

Iz te nedovršene serije zasad sa sigurnošću možemo identificirati tek četiri fotografije, i to po jednu snimku samostana u Krku i Glavotoku te dvije fotografije samostana sv. Marije Magdalene u Portu ${ }^{16}$. Albuminski otisci dviju fotografija u specifičnom su žutosmeđem tonu, dok je kod jedne fotografije Porta i one s motivom Glavotoka površina poprimila plavičasti, cijan ton. Tanki, sjajni papiri zalijepljeni su na stranice albuma, pa im je stražnja strana nedostupna. Fotografija krčkog samostana prilijepljena je na tanku papirnu podlogu. Sve

13 SMOKVINA 2001: 325. Dva kartona imaju bijelu pozadinu bez dekoracije s otiskom pečata u crnoj i ljubičastoj tinti, s natpisom: Fra Stanko Dujmović Trećoredac Sv. Frane.

14 S obzirom na slabiju kvalitetu i neuobičajeni dekorativni okvir, vjerojatno se radi o reprodukciji.

15 N. GRČEVIĆ 1972: 379; SEFEROVIĆ 1993: 195-196.

16 Fotografija interijera samostanske crkve na Školjiću, koja se pribraja ovoj seriji, vjerojatno je snimljena kasnije. Od ostalih odskače formatom, vrstom papira i pristupom motivu. 
su položenog formata, dimenzija približno 9 x $13 \mathrm{~cm}$. U sve četiri snimke Dujmović ugrađuje ljudske likove, promišljeno i odmjereno raspoređujući grupe i pojedine likove kao štafažu ili nenametljivo inscenirajući žanr prizor u vrtu samostana u Portu.

Krčki samostan snimljen je s blage uzvisine na sjeveru (s pozicije današnjeg vatrogasnog doma). U sliku nas uvodi leđima okrenuta ljudska figura u desnom kutu u prvom i skupina pješaka u drugom planu. Kompozicija je naglašeno horizontalna. Stupnjevito nizanje paralelno položenih gromača kulminira nizom građevina koje zauzimaju čitavu širinu kadra. U donjoj polovini snimke izmjenjuju se tamne mase niske vegetacije i linije suhozida, dok gornju zauzima monotona bjelina neba dinamizirana ritmiziranim vertikalama zvonika. Kadrom dominira bijeli pravokutnik sjeverne fronte samostana, sa zabatnim dijelom smještenim u središte.

Samostan u Portu snimljen je s juga, iz blagog donjeg rakursa. (Slika 4) Za razliku od prethodne fotografije, na kojoj zgrada samostana dominira bjelinom i volumenom, na ovoj je glavni motiv, samostanska zgrada, gotovo skriven iza krošnji stabala i ostale vegetacije. Tim više naglašena je vertikala osebujnog, karakterističnog krčkog dimnjaka. Sunčan je dan i u vrtu su dvojica fratara pod šeširima širokog oboda. Jedan je, sagnut do poda, zabavljen radom u zemlji, a drugi gleda ravno u objektiv. Druga fotografija iz Porta snimljena je iz istog smjera, ali s veće udaljenosti. Umjesto žanr-scene, promatra nas tek jedan dječak koji se nazire na bjelini zida.

Zbijeni glavotočki kompleks, okružen vegetacijom te morem i nebom, smješten je u središte kadra. Od skupine u prvom planu vide se samo glave.

Dujmović, kao sjajan portretist, na ovim fotografijama ne traži dopadljivi motiv, niti dokumentira izgled pročelja, već i ovdje portretira, dočarava karakter svakog od samostana. Franjevački samostan u Krku ugrađen je u gradske zidine, kraj sjevernih gradskih vrata, na najvišoj točki grada, dok je samostan u Portu smješten na idiličnom mjestu kraj mora, blizu ribarske lučice, okružen poljima i samostanskim vrtom. Glavotok je, pak, gotovo pustinjačka ekskluzija okružena šumom, na granici mora i neba.

Teško je ne primijetiti bitno manju kvalitetu izrade tih nekoliko sačuvanih veduta u odnosu na portrete iz istog razdoblja. Snimke su blijede, nedostaje oštrina, a na prikazima krčkog i glavotočkog samostana kadar je pomaknut po okomici. Očito je da iskustvo prikupljeno portretiranjem u kontroliranim, gotovo komornim uvjetima i pripadajuća oprema nisu zadovoljavali zahtjeve i okolnosti snimanja na terenu kakve si je preambiciozno postavio mladi fotograf. „Ispadanje“ likova iz prvog plana posljedica je krive procjene paralakse. Ipak, nenametljiva i uravnotežena kompozicija odaje istančan osjećaj za prostor i mjeru. Promišljeni, pomno odabrani i harmonično komponirani elementi govore o prirodno nadarenom, ali i verziranom oku mladog fotografa. 
Zanimljiva je fotografija simbolističkog senzibiliteta s prikazom dvojice fratara u činu molitve na grobu mrtvog subrata. Oba lika i kameni križ smješteni su uz desni rub, dok više od polovine lijeve strane zauzima čista bjelina. Fotografija je na albuminskom papiru kabinet-formata, zalijepljena na karton, s natpisom: Buić-Zamarija 1888, na grobu o. Josipa Dujmovića. Budući da nije signirana, atribucija je neizvjesna.

Nekoliko usputnih osobnih zabilješki vezanih uz bavljenje fotografijom i skroman broj očuvanih fotografija, čije je autorstvo nedvojbeno, upućuje na neke činjenice, važne za rani Dujmovićev fotografski opus. Unatoč razumnoj pretpostavci da su Dujmovićevi amaterski fotografski počeci povezani s netom inauguriranom komercijalnom proizvodnjom tzv. suhih ploča, indicije govore suprotno. U već citiranom dijelu ispovijesti, u kojem Dujmović opisuje svoje početke, navode se plemeniti metali te otrovni cijankalij kao materijali kojima se koristio u izradi fotografija. Upotreba tih materijala, a posebno cijankalija kao fiksira, dokazuje da je tada mladi bogoslov svoje prve negative razvijao koristeći se mnogo zahtjevnijim mokrim kolodijskim postupkom. Vodeći zadarski profesionalni fotograf, poduzetni Tomaso Burato, upotrebu suhih ploča u svom ateljeu, namijenjenih ,posebice nestrpljivim i nemirnim osobama i djeci“117, oglasio je 1879. Izuzetno rano, znamo li da su se prve suhe ploče u Beču počele proizvoditi u listopadu iste godine te da ,u njegovo doba provincijski fotografi nisu mogli nabavljati materijal u mjesnim trgovinama, nego neposredno od proizvođača ili veletrgovaca u većim gradskim središtima“ “. ${ }^{18}$ Budući da je na izložbi Britanskog fotografskog društva 1880. gotovo polovina fotografija bila snimljena s pomoću tradicionalnih, mokrih negativa ${ }^{19}$, ne začuđuje da se istom tehnologijom i nakon toga još neko vrijeme nastavio koristiti mladi početnik skromnih financijskih mogućnosti. Vidjeli smo da se albuminskim papirom koristi još 1895. i 1896. godine na skupnom portretu prilikom kongregacije i portretu o. Franje Kršića, iako Burato oglašava izradu portreta na brom-želatinskom papiru već 1880. godine. ${ }^{20}$ Fra Stankovi su prvi pozitivi na brom-želatinskom papiru oni s početka 20. stoljeća, iz 1902. i 1903. godine.

Prije no što zaokružimo najraniji kreativni period fotografa Stanka Dujmovića, još kratak osvrt na vezu između Parčića i Dujmovića, na neke činjenice i pretpostavke koje se nameću iz poznatih nam izvora. Možda nevažno, ali zanimljivo, barem na simboličkoj razini, koincidiranje je Parčićeva napuštanja franjevačkog reda i Dujmovićeva ulaska u Parčićev domicilni samostan na Glavotoku 1876.

\footnotetext{
17 SEFEROVIĆ 2009: 127.

18 Isto.

19 Isto.

20 Isto: 128.
} 
Nije teško zamisliti fascinaciju desetogodišnjeg mladića bez sumnje neobičnom pojavom svestranog znanstvenika (premda se s fotografskom opremom, zaostalom nakon Parčića, susreo tek sedam godina kasnije). S druge strane, kod seniora nije mogao proći nezapaženo interes koji je mladi fratar pokazao za ostavštinu cijenjenog bivšeg fratra, sada kanonika Hrvatskog zavoda sv. Jeronima u Rimu. Složeni onodobni fotografski postupci i tehnike, teško dostupna te skupa oprema i materijali, dugotrajni i zahtjevni procesi snimanja i razvijanja fotografija, umjesto prepreke, bili su poticajni mladom entuzijastu pa vlastite fotografije izrađuje već sljedeće godine. Dujmovićev zadarski fotografski put kao da nastavlja, u novoj generaciji, onaj Parčićev, tridesetak godina raniji. ${ }^{21} \mathrm{~S}$ manjim značenjem za fotografiju uopće, ali jednakim žarom i entuzijazmom te znatno duljim fotografskim stažem i listom sačuvanih fotografija. Stjecajem okolnosti, unatoč kompatriotskoj povezanosti, dijeljenju zajedničkih afiniteta i uzajamnog uvažavanja, životni putevi dvojice Krčana rijetko su se preklapali. Međutim, mladi je Dujmović čitavim tijekom boravka u Zadru na raspolaganju imao znanje i iskustvo Parčićeva fotografskog kolege, a vjerojatno i prisnog prijatelja, ljekarnika Josipa Brčića, prvog zadarskog profesionalnog fotografa i vrsnog fotografskog kemičara i tehnologa. ${ }^{22} \mathrm{U}$ tom se prijateljstvu vjerojatno krije tajna iznimno brzog i uspješnog svladavanja zahtjevnih onodobnih postupaka izrade i obrade fotografija. Pored toga, u Zadru, upravnom središtu Dalmacije, djeluje više profesionalnih ateljea i pojedinaca amatera pa su, nesumnjivo, i utjecaji dolazili s više strana. Otprilike u isto vrijeme zagrebački fotograf Standl za dio naknade kojom mu fotoklub plaća korištenje atelijerom „dužan je nove članove u fotografiranju podučavati“活. T. Burato u novinama Il Dalmatino iz 1893. oglašava: ,Gospodi fotografskim diletantima stavljamo na raspolaganje odgovarajući laboratorij, preuzimajući razvijanje, retuširanje i kopiranje njihovih negativa“ ${ }^{\text {"24. }}$. Ne treba odbaciti vjerojatnost da si je mladi entuzijast Dujmović platio poduku kod nekog od tadašnjih znalaca.

Crtica iz fra Stankovih memoara o susretu s generalnim definitorom E. Maricottijem govori o tome kako je jedna fotografija odškrinula vrata školovanju u Rimu, a time mu zacrtala i čitav daljnji životni put. „Ja sam pokazao o. Maricottiu jednu lijepu zbirku mojih fotografija, to je bilo onda nečuveno i nevidjeno od jednog amatera. Učinio sam i njemu uspjeli portret. Za priznanje odlučio je i sporazumio se sa Provincijalom da kad svršim nauke u Zadru i budem zaredjen da će me pozvati u Rim da usavršim nauke na Gregorijanskom sveučilištu. ${ }^{\text {"25 }}$

21 Isto: 159.

22 Veći broj Brčićevih radova nalazi se upravo u Parčićevoj ostavštini koja se čuva u Biskupskom ordinarijatu u Krku.

23 Iz izvještaja godišnje skupštine zagrebačkog Fotokluba 14. 3. 1897., M. GRČEVIĆ 1997: 15.

24 SEFEROVIĆ 2009: 159.

25 Provincija Franjevaca trećoredaca glagoljaša, Zagreb, Ostavština fra Stanka Dujmovića, svezak III. (f. 66r). 
Baš kako je i obećano, fra Stanku koncem 1890. stiže poziv iz Rima. „Koncem Oktobra 1890 General Emidio Maricotti pozvao me u Rim, da usavršim svoje nauke. (...) 21. Oktobra odputujemo, sledećeg dana sam u Rimu. Novi svijet, Eden, za me do tada Bodula." ${ }^{\text {"26 }}$

Zanimljivo je da Dujmović, koliko je zasad poznato, nikad nije fotografirao svojeg predšasnika, Parčića. U svojim memoarskim crticama spominje ga nekoliko puta. ${ }^{27}$ Jednom kad opisuje svečanost povodom svoje Mlade mise 1888.: „Dne 14. Oktobra slavio sam u Sv. Mandaljeni svoju Mladu misu. Imao sam puno braće redovnika, cijeli rod i lijepi broj pozvanika, među kojima Preč. Kanonik Parčić. Svečanost se razvila po narodnom običaju. Propovijedao o. Stjepan Ivančić, pjevali naši klerici.

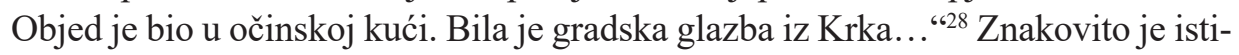
canje Parčića među svim uzvanicima. Posljednjih pet redovničkih godina Parčić provodi upravo u Glavotoku, gdje osniva Serafinsku tiskaru za koju sam izrađuje matrice i lijeva slova, tiska i slika liturgijska pomagala, prevodi i piše. Dana 20. travnja 1876. izlazi iz Reda, a u svibnju je već u Rimu, gdje preuzima mjesto kanonika Zavoda sv. Jeronima. Desetogodišnjeg Stjepana Dujmovića otac kaićem dovozi u Glavotok 1. veljače iste godine. Iako su dvojica bodula, desetogodišnje zaigrano dijete - tek pristigli kandidat - i sredovječni prezaposleni polihistor na odlasku, istovremeno na Glavotoku služili tek dva mjeseca, malo je vjerojatno da Parčić nije prepoznao potencijal mladoga Dujmovića. U vrijeme sudbinskog susreta Dujmovića i Maricottija 1886., Parčić je već 10 godina u Rimu te se može pretpostaviti da je imao prilike založiti se kod generala Maricottija za mladoga zemljaka.

Iako u citiranoj memoarskoj bilješci ${ }^{29}$ izjavljuje da prvi period njegova ,fotografičkog života“" završava naprasnim prekidom fotografiranja samostana zbog malarije u Martinšćici 1887., tu bih vremensku razdjelnicu pomaknuo prema naprijed za gotovo čitavo desetljeće. Portrete o. Kršića (datirane u 1896.) i o. Leonarda te skupne portrete prigodom kongregacije 1894. (1895.?) ${ }^{30} \mathrm{i}$ one talijanske obitelji odlikuje veća oštrina, kontrast i zasićenost tamnih tonova ${ }^{31}$. Spomenuta

26 Provincija Franjevaca trećoredaca glagoljaša, Zagreb, Ostavština fra Stanka Dujmovića, svezak III. (f. 68r).

27 Činjenica je da Dujmović nigdje u svojim uspomenama ne spominje niti jednog od svojih fotografskih uzora, učitelja ili mentora, pa čak niti kolege fotografe s kojima se zasigurno susretao i družio, osim po jedanput, usputno, Felixa Laforesta i ,slijepog fotografa Jelasku“, obojicu u Herceg Novom.

28 Provincija Franjevaca trećoredaca glagoljaša, Zagreb, Ostavština fra Stanka Dujmovića, svezak III. (f. 67r).

29 Vidi bilj. 9.

30 Na dvjema sačuvanim kopijama navedene su dvije različite datacije.

31 Jesu li ove razlike posljedica prijelaza s tehnologije mokre na suhu ploču negativa, što bi značilo da se mokrom pločom koristio prilično dugo, teško je reći. 
skupna fotografija, snimljena u dvorištu obiteljske kuće, promjenom u rasporedu snimljenih, unatoč njihovoj i dalje krutoj impostaciji i tretmanu prostora, nagovještava skori obrat. Značajna, korjenita promjena nastupa nešto kasnije, a vidljiva je tek na fotografijama koje snima prvim odlaskom u SAD. Više od 200 fotografija nedvojbene atribucije, snimljenih u razdoblju od nepunih četiriju godina, između 1907. i 1911. godine, priča sasvim drugim jezikom od ranijih radova. Premda se fra Stanko u samim počecima dokazao kao nadaren, likovno obrazovan, sposoban za brzo usvajanje novih znanja i vještina, fascinantan je skokovit kvalitativan pomak koji ostvaruje u kratkom vremenu. Dva su čimbenika koja su sigurno pripomogla ovakvom razvoju; tehnološki napredak koji je omogućio da se manjim i lakšim kamerama i osjetljivijim objektivima snima u manje povoljnim uvjetima, s kraćim vremenima eksponiranja te promjena sredine, drugačije podneblje i socijalno okruženje koji pred fotografa postavljaju drugačije zadatke i nužno rezultiraju promjenom pogleda. Uz to, evidentna je informiranost o suvremenim kretanjima u fotografiji. ${ }^{32}$ Iako je tada vladajući piktorijalizam, koji kao popudbinu vjerojatno donosi iz Europe, prihvatio kao konstantu, znao je postaviti mjeru nikad ne dopuštajući da manipulativnim tehnikama u negativ ili pozitiv osjetno kompromitira ili negira izvornu fotografiju ${ }^{33}$. Nekoliko primjera koloriranja pejzaža možemo promatrati kao eksperiment. Koristio se retuširanjem fotografija, ali ne često i s minimalnim intervencijama. Njegove su fotografije „obojene“ piktorijalizmom tako što se koristi nekim izražajnim sredstvima svojstvenima tom pravcu, prvenstveno izbjegavanjem oštrog fokusa i zamućivanjem detalja, a zapravo bi ga se tek u rijetkim slučajevima moglo nazvati istinskim piktorijalistom. U spaldinškom periodu Dujmovićeva se fotografija kreće na tromeđi piktorijalizma, naturalističke fotografije P. H. Emersona, naročito kod animalističkih i žanr-prizora te onoga što će Lewis Hine tek kasnije imenovati interpretativnom fotografijom.

Crni, u kožu uvezani fotoalbum s kartonskim stranicama za umetanje fotografija, sa secesijskom bordurom u slijepom tisku, pozlaćenim natpisom Souvenir Post Cards i naljepnicom Spalding Collega na naslovnici, ispunjen je fotografijama i ulijepljenim, crnom tintom ispisanim stranicama. Radi se o sjećanjima, rekapitulaciji zbivanja tijekom boravka u Spaldingu, malenom zabačenom naselju u Nebraski ${ }^{34}$, gdje fra Stanko biva poslan da oformi franjevačku trećoredsku zajednicu i školuje

32 Nadajmo se da će buduća istraživanja na policama samostanskih knjižnica otkriti bar dio literature koju Dujmović spominje u bilješkama. Ovdje prvenstveno očekujemo Naturalistic photography for students of the art P. H. Emersona, izdanu 1889.

33 U ekscese ove vrste, drastično kolorirajući pozitive nekoliko djevojačkih portreta, upustio se desetak godina kasnije, 20-ih godina 20. stoljeća, postižući zanimljiv učinak.

34 Spalding je, po Dujmoviću, tada imao oko 500 stanovnika, a toliko ima i danas. Provincija Franjevaca trećoredaca glagoljaša, Zagreb, Ostavština fra Stanka Dujmovića, album s rukopisom, str. 5, https://www.census.gov/prod/cen2010/cph-2-29.pdf. 
mlade svećenike koji će nastaviti njegovu misiju. Na samom početku teksta u kojem fra Stanko opisuje zbivanja tijekom troipolgodišnje pionirske misije stoji: „Sve slike sabrane u ovom Albumu učinio sam ja potpisani P. Stanko Dujmović u Spalding-u, Nebraska U.S.A. od godine 1907 do godine 1911. Pošto je moja misija i rad u tom mjestu najvažnije cijelog mog redovničkog života ovo hoću da sve ispripovjedim i opišem. I molim čitatelje ovog memoira da ne trgaju slike i ne kvare ove knjige jer se ufam da će dalji potomci za me Boga moliti i požrtvovno raditi za mili svoj Treći Red“335. Tom nam je bilješkom fra Stanko uvelike olakšao trud, otklonivši svaku sumnju u autorstvo nad 184 fotografije iz ovog albuma i još četrdesetak iz drugog, manjeg albuma, a koje su ili duplikati ili formalno i sadržajno ne odudaraju od prethodnih. Najveći broj fotografija razvijen je na VELOX papiru s pozadinom u formi dopisnice $(87 \times 137 \mathrm{~mm})^{36}$, manji broj na neoznačenom papiru $(101 \times 153 \mathrm{~mm})$, a po nekoliko fotografija razvijeno je na drugačijim, manjim ili većim formatima. Zastupljene su sve vrste površina, mat, polumat, satinirana i sjajna, a nekoliko ih je, koloriranih, na papiru grublje teksture.

Album iz Spaldinga priča je o misionarskom pothvatu, ali i pothvat sâm. Niz od 184 fotografije zaokružena je cjelina povezana mjestom i vremenom snimanja, sazdana od niza manjih epizoda i pojedinačnih prizora. Neobičnu i dojmljivu fotografsku priču o svoje tri i pol američke godine fra Stanko Dujmović ispričao nam je konvencionalnim, ali i onim manje uobičajenim portretima, pejzažima pustopoljina Nebraske i idiličnim prizorima, vedutama američkog sela, žanr-scenama, pastoralnim motivima. (Slika 5-9) Premda bi se čitav album mogao promatrati kao veliki romantičan snovit spomenar, nerijetko fotografije imaju dokumentarni, pa čak i reportažni karakter. (Slika 10-11) Stranice fra Stankova rukopisa ugrađene u album nerijetko govore o teškim trenucima sukoba i čestim preprekama na koje je nailazio tijekom boravka u Spaldingu. Fotografije, naprotiv, zrače nepatvorenom životnom radošću, a komentari koje nerijetko dopisuje na rub fotografija prožeti su rafiniranim, odmjerenim bodulskim humorom. Portretirane, većinom mlada i optimistična lica, smješta među rascvale proljetne grane ili ih formira u skupine koje zrače opušteno, prisno, prijateljski. (Slika 12-14) Dotad uobičajenu strogu frontalnu simetričnu formaciju koja ispunjava kadar smjenjuju skupine oblikovane po logici prizora i ambijenta, nerijetko uklopljene u vedutu ili okružene prirodom. Vrhunac je invencije i odmaka od konvencija fotografija skupine mladića garniranih na automobilu i oko njega, gotovo ga prekrivši, s dvojicom likova u prvom planu koji se napadno okreću od oka kamere, dinamizirajući prizor, te mladićem koji sjedi na prozoru. (Slika 15) U tom se albumu Dujmović dokazao kao vrsni pejzažist i

35 Provincija Franjevaca trećoredaca glagoljaša, Zagreb, Ostavština fra Stanka Dujmovića, fotografski album iz Spaldinga.

36 Nekoliko je primjeraka na papiru marke CYKO, proizvođača fotografske opreme ANSCO iz Binghamtona, NY. 
vedutist te je prava šteta to što je nakon Spaldinga gotovo u potpunosti zanemario te teme. Gotovo u svim tim prizorima pojavljuje se ljudski lik, ili kao štafaža ili kao ravnopravan, konstitutivan element. $\mathrm{Na}$ tragu ponajboljih piktorijalističkih ostvarenja, koristi se stablima i njihovim granama, superponirajući ih arhitekturi ili služeći se njima kao scenografijom. (Slika 16-18) Posebno su zanimljiv segment tog albuma žanr-prizori i prikazi životinja. (Slika 19-21)

Nakon Spaldinga, fra Stanko vraća se u Rim i ondje ga zatječe Prvi svjetski rat. Za razliku od svih ostalih Hrvata koji kao državljani Austo-Ugarske, Italiji neprijateljske države, bivaju protjerani, on ostaje u Rimu tijekom čitavog rata, ali zbog opreza ne fotografira i ne vodi dnevničke bilješke. Prve sljedeće fotografije snima tek dvadesetih godina. Premda od tada pa nadalje radi gotovo isključivo portrete, s iznimkom tek nekoliko interijera i veduta, rezultati više nikad neće imati konzistenciju kakva odlikuje njegov dotadašnji rad, a s obzirom na broj sačuvanih fotografija, drastično se smanjila i produkcija. Razloge treba tražiti u velikoj odgovornosti i brojnim dužnostima te čestim promjenama boravka. Dvadesete i tridesete godine u fotografiji iznimno su dinamičan period, mijene su korjenite i brze te Dujmović, već u šestoj deceniji života i pritisnut obvezama, neminovno gubi korak s promjenama.

Niz portreta i autoportreta nastalih nakon rata, neujednačenih kvalitetom, formatom, vrstom papira i tehnologijom izrade teško je precizno periodizirati i sa sigurnošću atribuirati. Rijetki su radovi autorizirani, njih tek nekoliko, među njima ne i najbolji. Ipak, većina je radova nedvojbeno Dujmovićevo djelo. Period do 1926. obilježava nekoliko posebno zanimljivih portreta. Četiri skupna portreta trećoredaca, snimljenih u samostanima u Portu i Krku i datiranih 1922. i 1925. godine, osim što su vrsni primjeri žanra, korisni su u periodizaciji niza istovremeno nastalih portreta pojedinaca s tih slika. (Slika 22) U seriji od šest portreta na papiru grublje teksture, grubo rezanih bridova (oko $12 \times 9 \mathrm{~cm}$ ), obrađenih plemenitim postupkom, pojavljuju se neka od lica sa spomenutih skupnih portreta. (Slika 23-25) (SL) Portreti su izrađeni u Zadru i, osim fratara, prikazuju neke članove njihovih obitelji. Dramatično osvijetljeni, naglašeno kontrastni profili i poluprofili čine konzistentan niz sjajnih karakternih studija. Signaturom je potvrđeno autorstvo nad istodobno nastalim nizom od triju izražajnih portreta franjevaca Radića, Vidulića i Sorića. Ta tri portreta, kojima možemo pribrojiti portret Gašpara Mašine iz Preka, u čišćem obliku, lišenom obimne postprodukcije, koreliraju s prethodno spomenutim nizom.

U 1922. godinu datirana je kolorirana panorama fra Stankova rodnog Porta, snimana s mora. S obzirom na godinu nastanka i način koloriranja naknadnim interveniranjem akvarelom ili pastelama na površinu pozitiva, sličan onom koji je primjenjivao na nekoliko fotografija iz Spaldinga, velika je vjerojatnost da se radi o fra Stankovoj fotografiji. (Slika 26)

Između 1926. i 1931. fra Stanko je treći i posljednji put za života u Americi, gdje tijekom pet godina služi kao župnik u više gradova u Pensilvaniji. Brojnim 
kontaktima i suradnjom sa župljanima i našim iseljenicima razvila su se prisna prijateljstva, o kojima svjedoče portreti više članova obitelji, npr. Robič, Frketić i Poljak ili zborskih pjevača, poslužitelja, prvopričesnika. (Slika 27-28) Tu fazu odlikuje mnogo ležerniji pristup, oslobođen dramatike i patosa. Gotovo su svi portreti u interijeru, uz svakodnevni namještaj i zatečenu pozadinu. Postav portretiranih i dalje je namješten, konvencionalan, ali zadovoljna, spontano nasmiješena lica djeluju opušteno.

Dujmović je od samih početaka kao motiv volio uzimati vlastiti lik i obradio ga je, s formalnog i sadržajnog gledišta, na mnoge, različite načine. Dodjeljivao si je razne uloge, ne ustručavajući se i našaliti na vlastiti račun. Autoportreti iz te, kasne stvaralačke faze, za razliku od spomenutih portreta župljana, teže monumentalizaciji naglašenom ozbiljnošću izraza, krutom pozom i dramatičnim osvijetljenjem. Najdojmljiviji je i među najboljim fotografijama uopće markantni profil u habitu i kaloti. (Slika 29)

Posljednju američku fazu obilježila su i tri prikaza interijera hrvatske župne crkve u Pittsburghu. (Slika 30) U snimci pogleda iz bočne lađe k svetištu raspored i naglašena upotreba arhitektonskih elemenata, stupa i arhitrava neodoljivo podsjeća na sliku Bičevanje Krista Piera della Francesce, ali na tome staje sva sličnost. Oku koje se koleba između glavnog oltara s lijeve strane i sporednog s desne, bližeg i daljeg, velikog i malog, jedino uporište i stabilnost pruža stup, izoštren i nesmiljeno postavljen u prvi plan i središte kadra te raspelo postavljeno neposredno uza nj i s njim tonalno i fokalno ujednačeno. Simbolika Krista kao središta i oslonca time postaje neupitna. Ispred te je crkve vjerojatno snimljena i posljednja fra Stankova američka fotografija, s naslovom: The Last Visit 8/8 1931.

Pored svega navedenoga, ostaje stanovit broj fotografija čiju atribuciju tek treba potvrditi. Kod nekih fotografija, među kojima su većinom portreti, nedvojbena je atribucija, ali je neizvjesno vrijeme nastanka. Neke fotografije, čije je postojanje dokumentirano, tek se trebaju pronaći, odnosno identificirati među raspoloživima. Nadajmo se da ćemo imati sreće s pronalaženjem ili identifikacijom nekih fotografija o čijem postojanju ima indicija, među kojima su i portreti djece nadvojvode Karla Stjepana Austrijskog, snimljenih u Velom Lošinju na prijelazu stoljeća, a koje Dujmović spominje u svojim sjećanjima. (Slika 31-35)

U osam fotografskih albuma, između uglavnom Dujmovićevih fotografija, ima i radova drugih autora. Za pregršt dizderijevskih portreta iz najstarijeg albuma autori su poznati jer su gotovo svi opremljeni kartonima s nazivom studija. Za određen broj fotografija, među kojima ima vrsnih ostvarenja, tek se treba utvrditi autorstvo. Zanimljiv niz četiriju vrsnih reportažnih fotografija kojima je zabilježen posjet papinskog nuncija Herceg Novom 30-ih godina 20. stoljeća, s obzirom na pečat atelijera na poleđini, vjerojatno je djelo ondašnjeg profesionalnog fotografa Feliksa Laforesta, člana glasovite obitelji fotografa. 
Dujmović je eksperimentirao i sa stereofotografijom. Od te vrste sačuvale su se tri cjelovite snimke, i to Krka, ${ }^{37}$ Malinske i šireg prostora Dubašnice te jedna strana stereografije predjela Uhlić u Portu. Stereografija skupine ljudi pod gustom krošnjom stabla, nazvana Pod kuprivom, na nepoznatoj lokaciji, nečijim je neznanjem rasparena i ulijepljena $u$ dva različita albuma.

Početkom 1931. u Millwallu je Dujmović teško obolio i nikad se u potpunosti nije uspio oporaviti. Nakon povratka, zadovoljan uspješno dovršenim samostanom na zagrebačkom Ksaveru, velikim dijelom zahvaljujući njegovu zalaganju i trudu, povlači se u Herceg Novi, gdje provodi posljednje godine života i naposljetku umire 25. veljače 1940. godine. Iz tog razdoblja ostalo je nekoliko karakterističnih fotografija svećenika i časnih sestara u bujnoj vegetaciji te pregršt portreta malih formata. Znakovito je da se upravo tim minijaturama - radi se o formatima oko $5 \mathrm{x}$ 4 do $9,5 \times 7 \mathrm{~cm}$ - dostojanstveno oprostio od fotografije. Napokon se oslobodivši tereta kompleksa neostvarenog slikara, počinje se izražavati čistom fotografijom. Nepretenciozni portreti lišeni svega suvišnoga, snimljeni u zatečenim ambijentima i raspoloživom rasvjetom, zrače lakoćom pristupa i izrade, a kroz nasmiješena ili zamišljena dječja lica, suzdržane i smjerne časne, prizor oca i sina, žene koja kupi robu s konopa ili djevojke s ružom prosijava autentična emocija. (Slika 36-39)

Fra Stanko Dujmović pripada kategoriji stvaraoca koju Želimir Koščević opisuje kao „poštene amatere i entuzijaste“, koji su „posve amaterski snimali svoj obiteljski krug, prijatelje, okolinu ili putne impresije “38. Za razliku od Parčićeva pionirskog, eksperimentalnog pristupa i doprinosa fotografiji polovinom 19. stoljeća, Dujmović korača utabanim stazama, korektno vladajući izražajnim sredstvima medija. U ranoj mladosti savladana tehnologija i likovno iskustvo stečeno samoobrazovanjem solidan su temelj na kojem počiva Dujmovićev fotografski opus. Vođen duhom tadašnjeg vremena, prihvaća piktorijalizam, a neiživljen san da postane slikarom do pred sam kraj ne dopušta mu da ga nadiđe i zakorači u prostore čiste fotografije. Pojedini radovi, naročito iz vremena prvog boravka u SAD-u, između 1907. i 1911., nagovješćuju kreativni potencijal za reportažnu i tzv. life-fotografiju koji, nažalost, biva zatomljen disciplinom, ograničenim financijama i obavezama. Fotografski album s rukopisnom ispovijesti iz Spaldinga dokument je kolektivnog pothvata, subjektivno svjedočanstvo i jedinstveni fenomen u povijesti hrvatske fotografije. Tim se albumom Dujmović upisuje i u povijest fotografije SAD-a. Kao osvjedočeni humanist (rijetke su fotografije bez ljudskog lika), najčešće snima portrete. Fotografsku avanturu započeo je dizderijevskim portretima u Zadru i zaključio portretnim minijaturama čiste fotografije u Herceg Novom.

$\mathrm{Na}$ stogodišnjicu ujedinjenja franjevačke zajednice u Spaldingu s Redom u Rimu 2006. hrvatska provincija Franjevaca trećoredaca glagoljaša američkoj

37 SMOKVINA 2015: 31.

38 KOŠČEVIĆ 2000: 43. 
braći poklonila je pretisak fra Stankova albuma s bilješkama iz Spaldinga. Tim je činom osviještena uloga hrvatskih trećoredaca, posebno fra Stanka Dujmovića u formiranju franjevačke trećoredske zajednice u SAD-u. Ove, 2016. godine, na fra Stankov 150. rođendan, po želji američkih trećoredaca dogovoreno je preseljenje njegovih zemnih ostataka u Loretto u Pensilvaniji, sjedište Provincije Presvetog Srca Isusova u SAD-u, provincije za čije je osnivanje najzaslužniji. (Slika 40)

\section{Bibliografija}

\section{Izvori}

Provincija Franjevaca trećoredaca glagoljaša, Zagreb, Ostavština fra Stanka Dujmovića, svezak III. i IV. (bez signatura i paginacije)

Provincija Franjevaca trećoredaca glagoljaša, Zagreb, Ostavština fra Stanka Dujmovića, album fotografija s rukopisnim bilješkama. (bez signatura i paginacije)

Provincija Franjevaca trećoredaca glagoljaša, Zagreb, Ostavština fra Stanka Dujmovića, sedam albuma s fotografijama. (bez signatura i paginacije)

\section{Literatura}

BOZANIĆ, Anton. 2010. Omišalj - drevna župa i iseljenici u New Yorku. Omišalj: Župa Omišalj.

DUBROVIĆ, Ervin (ur.). 1995. Arte miracolosa, stoljeće fotografije u Rijeci. Rijeka: ICR.

GRČEVIĆ, Mladen. 1965 (1997). Umjetnička fotografija u Hrvatskoj - 1891-1940. Zagreb: IPU (reprint), DPUH.

GRČEVIĆ, Nada. 1972. Fotografska ostavština Dragutina Parčića. Radovi instituta JAZU u Zadru 19: 373-392.

GRČEVIĆ, Nada. 1977. Rana fotografija u Zadru. Zadar: Kulturno-historijski odjel Narodnog muzeja.

GRČEVIĆ, Nada. 1981. Fotografija devetnaestog stoljeća u Hrvatskoj. Zagreb: Društvo povjesničara umjetnosti Hrvatske.

GREGOV, Nikola. 1965. In memoriam o. Stanka dr Dujmović. Vjesnik Provincije franjevaca trećoredaca glagoljaša 2: 37-40.

GREGOV, Nikola. 1965b. In memoriam o. Stanka dr Dujmović, Vjesnik Provincije franjevaca trećoredaca glagoljaša 2: 66-73.

Hrvatski biografski leksikon, s. v. „Gjivoje, Antun“.

KOŠČEVIĆ, Želimir. 2000. Fotografska slika - 160 godina fotografske umjetnosti. Zagreb: Školska knjiga.

MALEKOVIĆ, Vladimir, Marija TONKOVIĆ. 1994. Fotografija u Hrvatskoj 1848-1951. Zagreb: Muzej za umjetnost i obrt.

SEFEROVIĆ, Abdulah. 1993. Svjetloslikar s Galevca. Zadarska smotra XLII/3: 187-196. SEFEROVIĆ, Abdulah. 2009. Photographia Iadertina. Zagreb: Kapitol. 
SMOKVINA, Miljenko. 2001. Hrvatska na povijesnim fotografijama. Zagreb: Veble commerce.

SMOKVINA, Miljenko. Krčki „dilettant fotograf“ fra Stanko Dujmović. Krčki kalendar 2015: 7-31.

U. S. Census Bureau. 2010. Census of population and Housing. https://www.census.gov/ prod/cen2010/cph-2-29.pdf (posjet 15. 9. 2016; zadnja izmjena 19. 7. 2012).

\section{Friar Stanko Dujmović (1866 - 1940) as a Photographer}

Stanko Dujmović (1866-1940), a Franciscan Tertiary, took up photography during his school days in Zadar. He quickly mastered the wet collodion process and achieved the quality of contemporary professional portrait photographers. He served at some of the highest positions within the Province and the Order. He founded the Spalding College for education of young priests between 1907 and 1911 in Spalding, Nebraska, and worked on organizing the Order. An album of authorized panoramas, group or individual portraits in a specific setting, genre scenes and memoires have been preserved from this period. Photographs from this period are characterized by a mixture of moderate pictorialism, naturalistic photographs of P. H. Emerson and interpretive photography, as it was later named by Lewis Hine. Consistency in style and diversity of subject characteristic of the Spalding album would not be repeated. From then on, he almost exclusively produced portraits and self-portraits. He was taking pictures of his confreres, coworkers, friends and their families in the homeland and the USA, where he returned for two more times. In the last phase he settled for pure photography. A series of unpretentious portraits in small format is characterised by direct approach, simplicity and authentic emotion. His earthly remains will be transferred to Loretto, PA, owing to his merits in founding the first Province of the Third Order Regular in the USA, now the Province of the Most Sacred Heart of Jesus.

Keywords: Franciscan Tertiaries, photography, wet collodion process, pictorialism, naturalistic photography, interpretive photography, Krk, Zadar, Spalding, Nebraska, Pennsylvania.

Ključne riječi: franjevci trećoreci, fotografija, mokri kolodijski postupak, piktorijalizam, naturalistička fotografija, interpretativna fotografija, Krk, Zadar, Spalding-Nebraska, Pensilvanija.

Damir Sabalić Konzervatorski odjel u Rijeci Ministarstva kulture Republike Hrvatske HR-51000 Rijeka, Užarska 26 sabalicd@gmail.com 


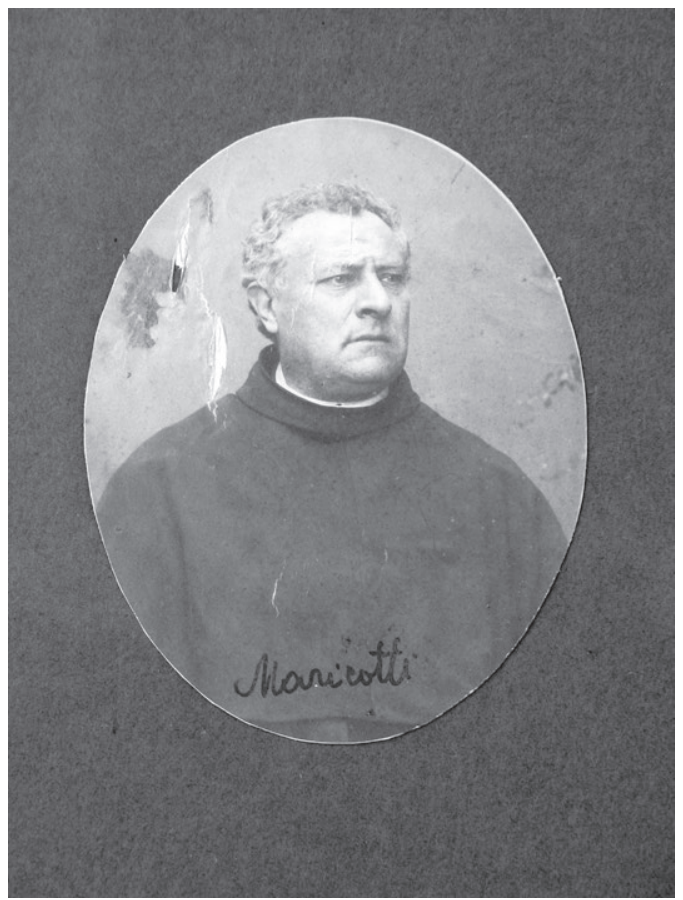

Slika 1: o. Emidio Maricotti

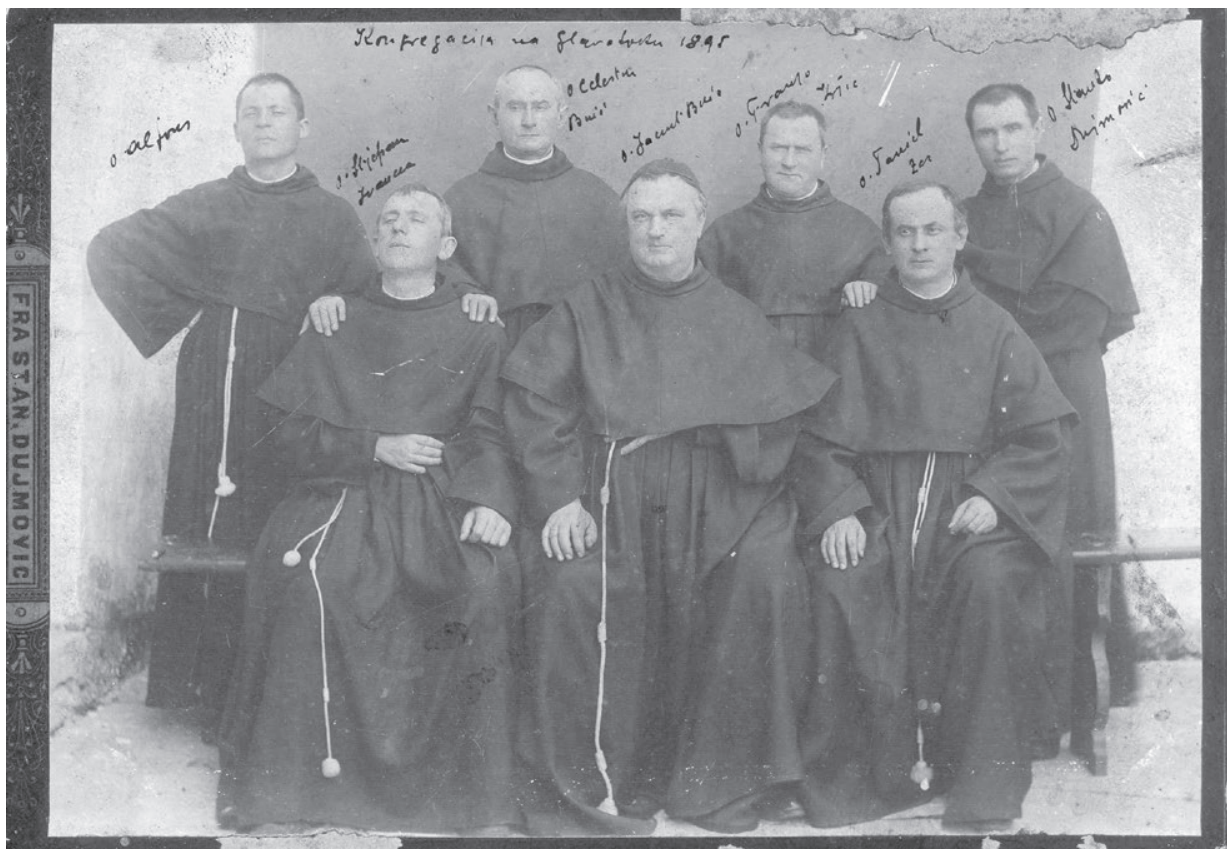

Slika 2: Glavotok, 1895 


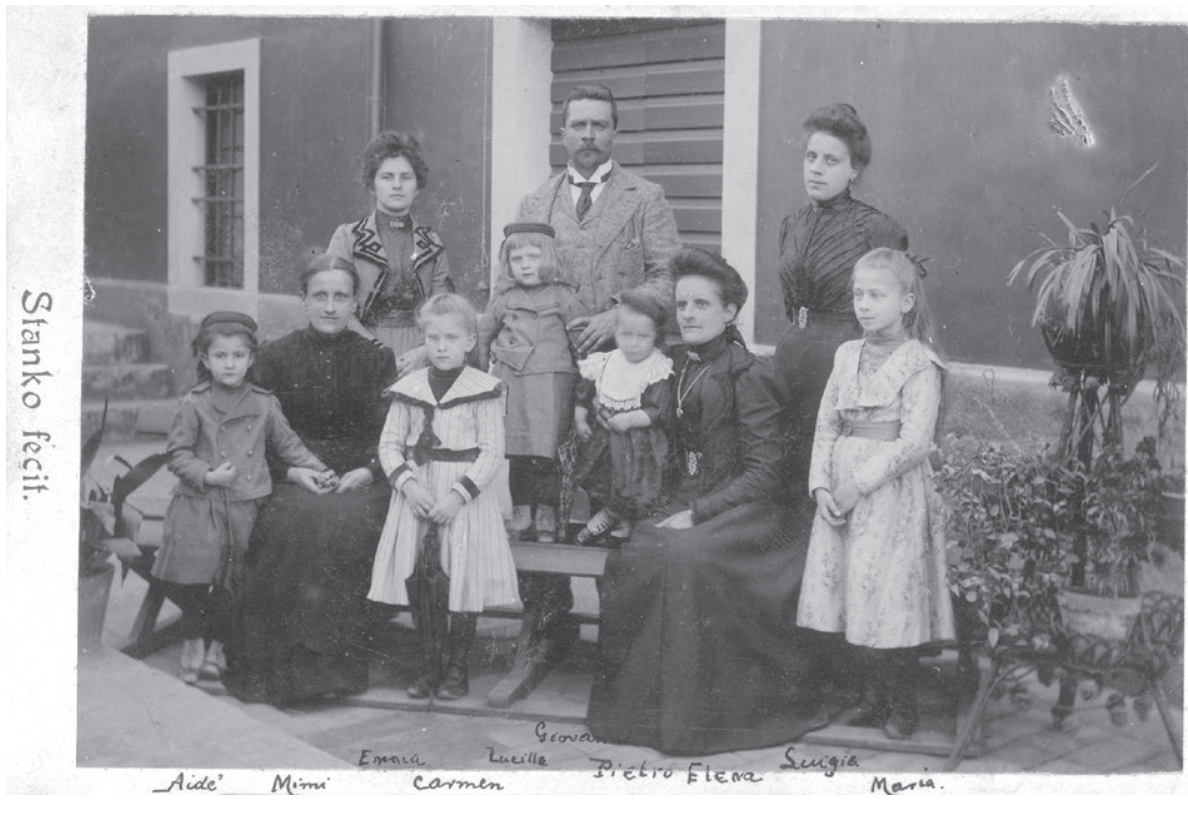

Slika 3: Talijanska obitelj

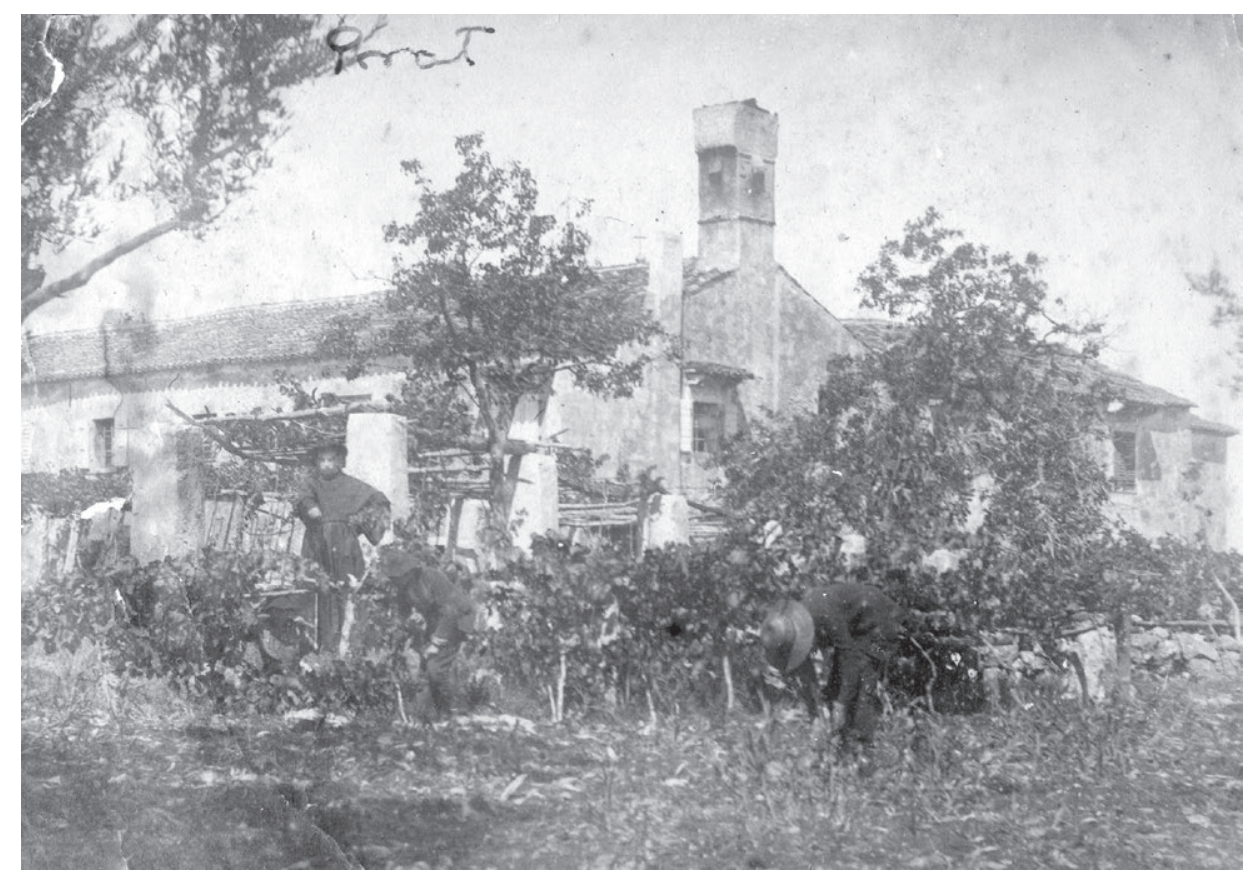

Slika 4: Franjevački samostan u Portu 


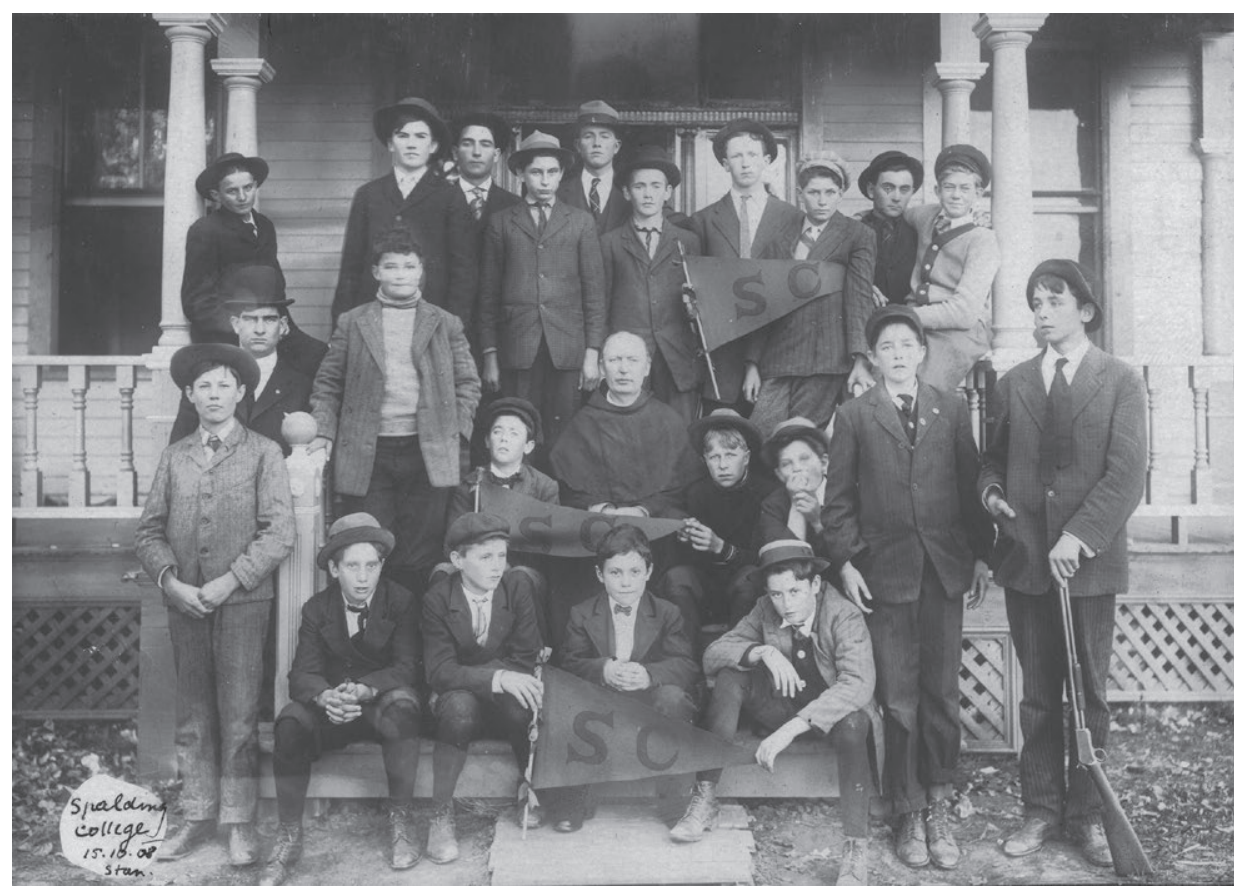

Slika 5: Spalding College 15.10.1908.

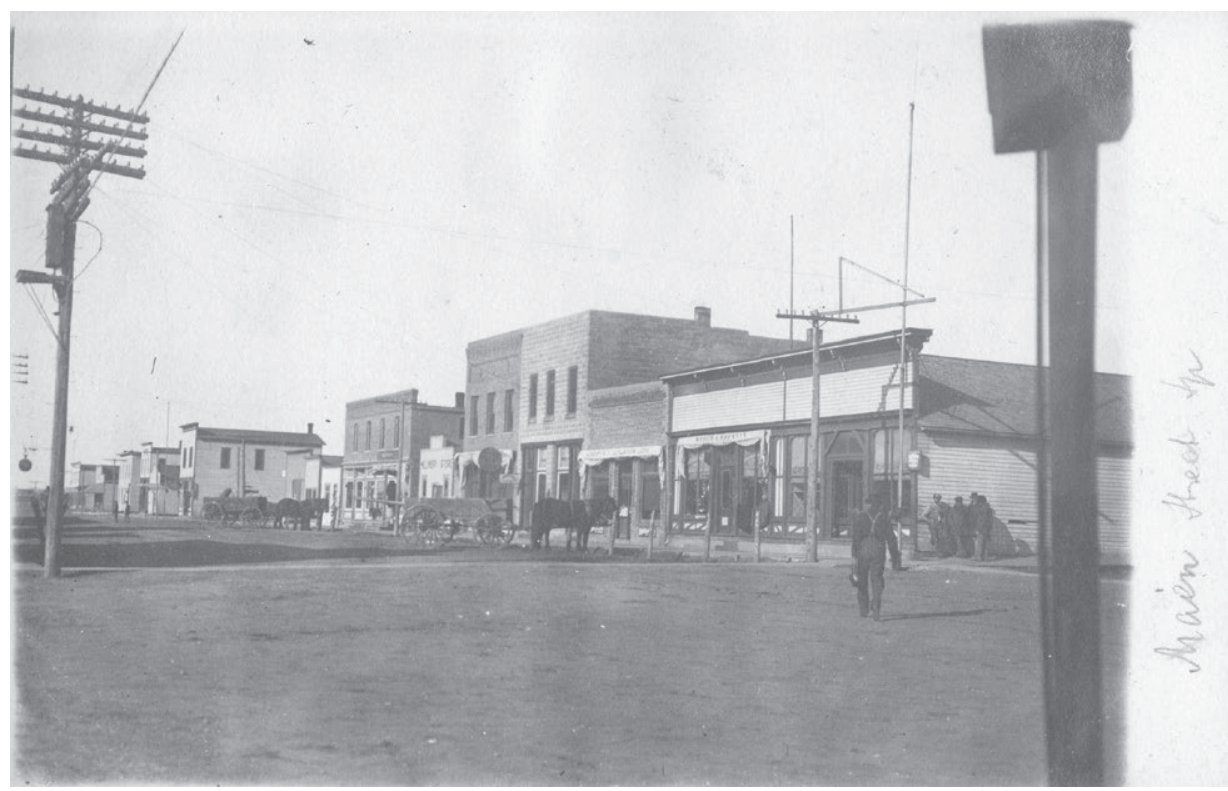

Slika 6: Spalding, glavna ulica 


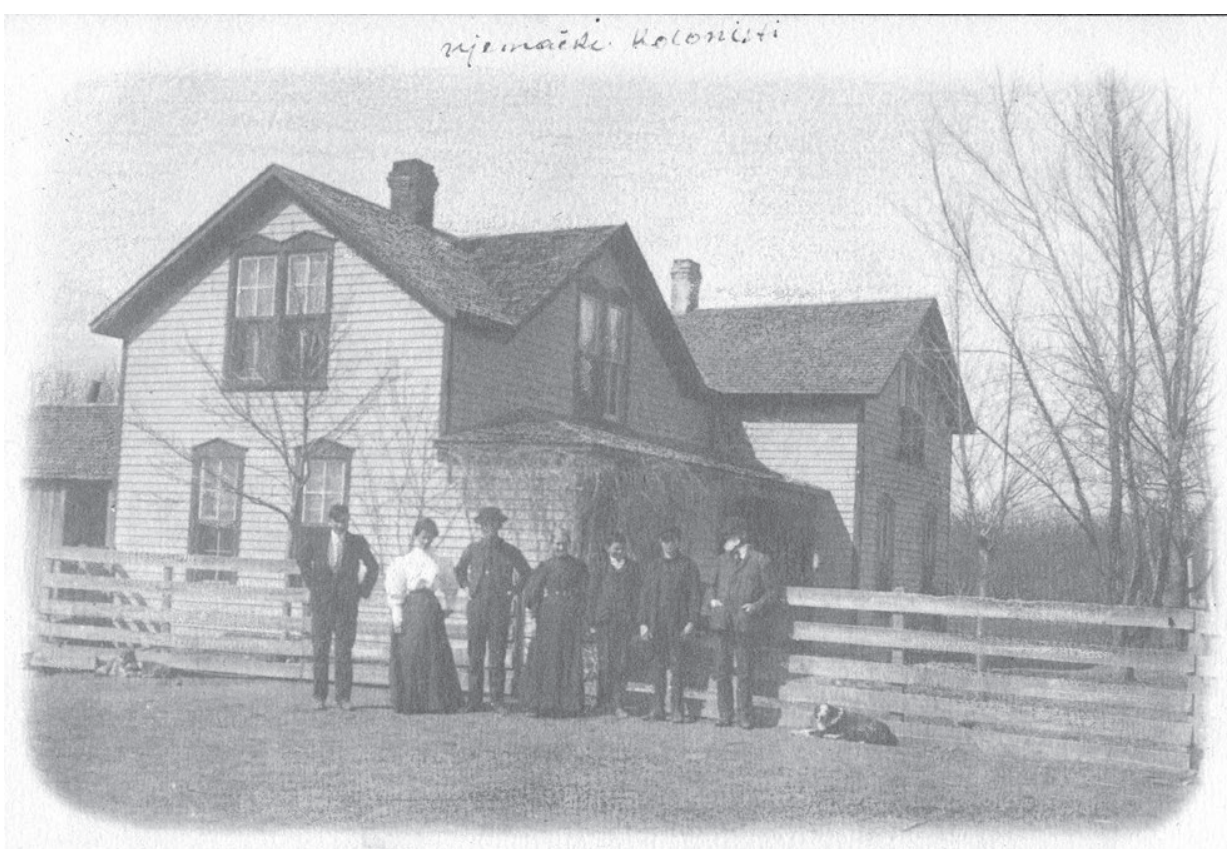

Slika 7: Njemački kolonisti

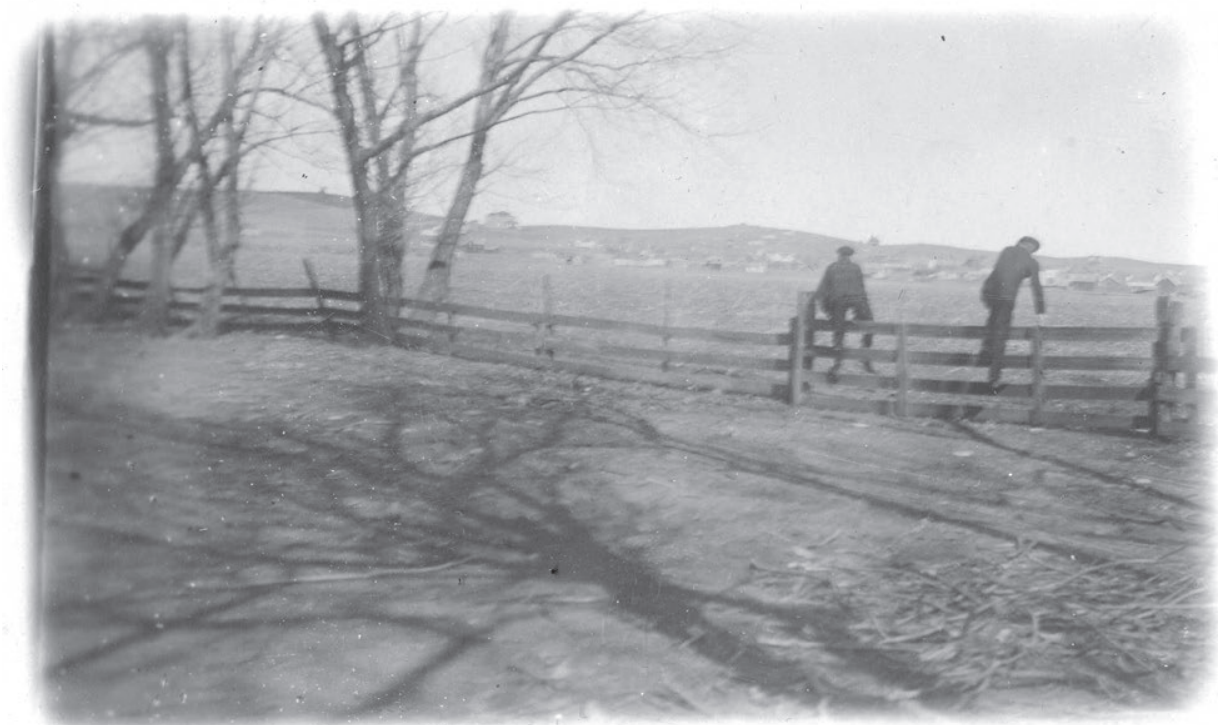

Slika 8: Spalding, Nebraska 


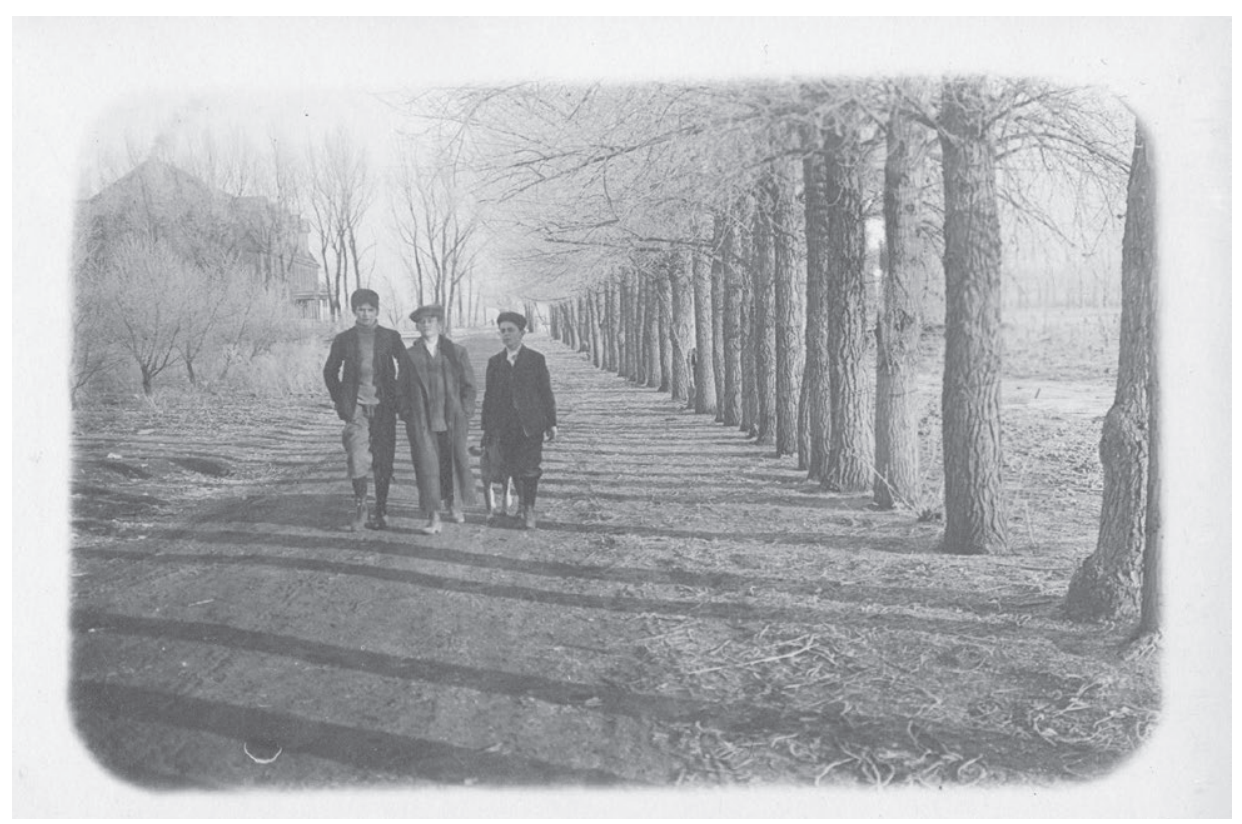

Slika 9: Spalding, Nebraska 2

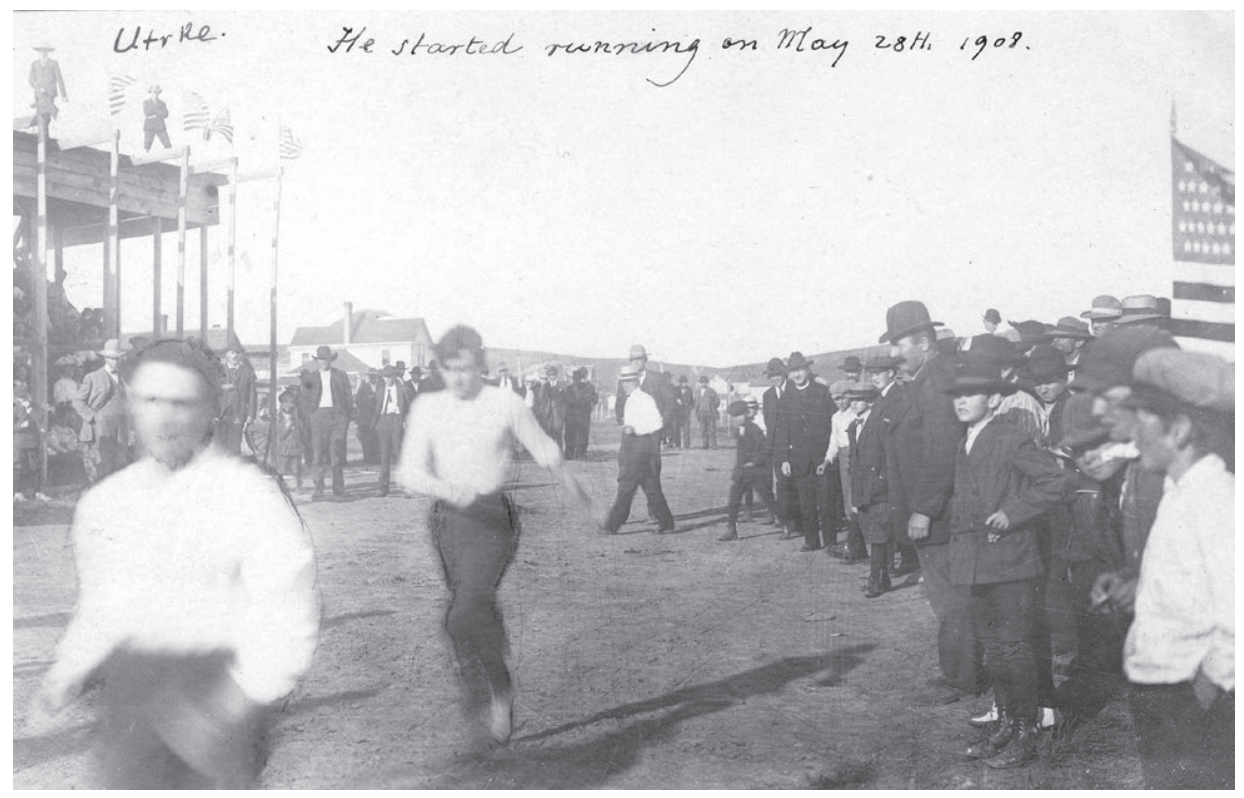

Slika 10: Utrka 


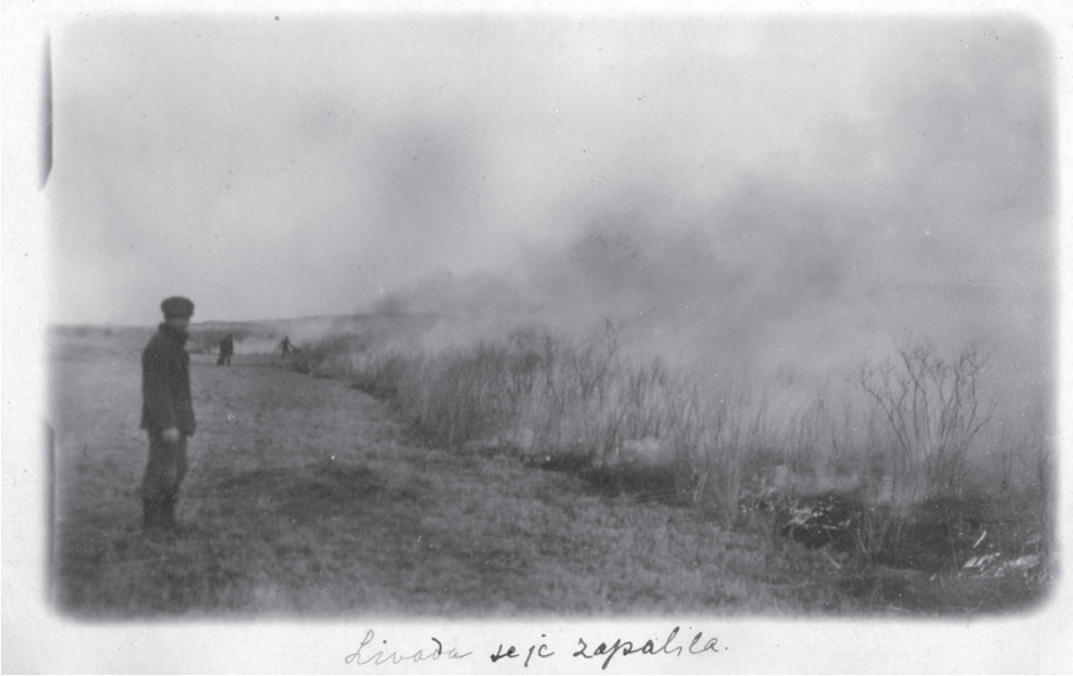

Slika 11: Livada se zapalila

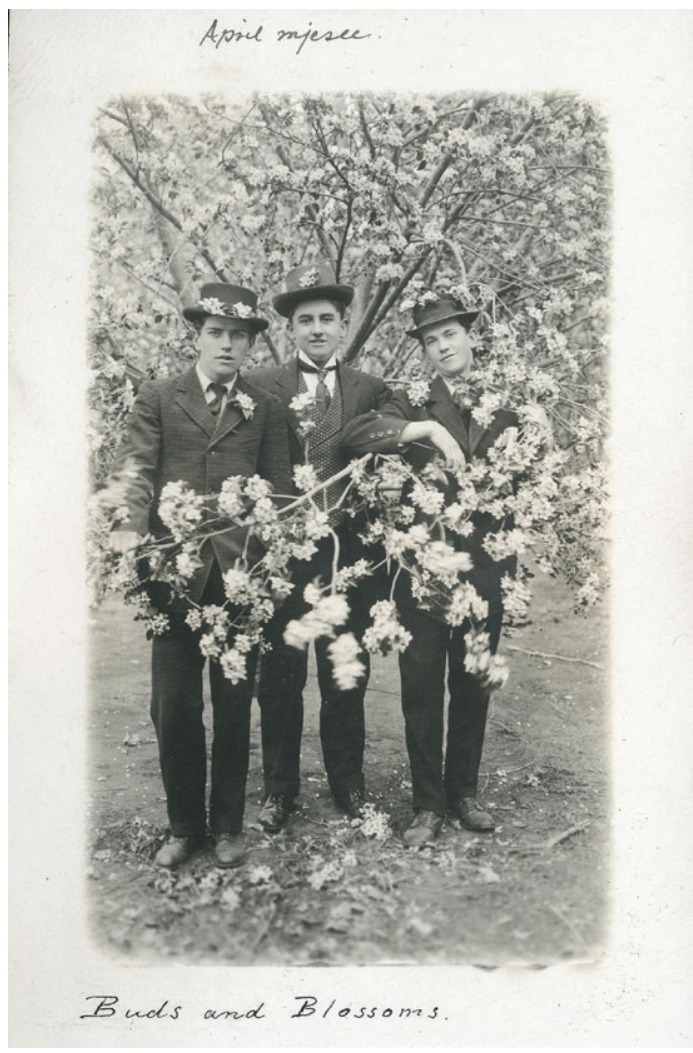

Slika 12: Buds and blossoms 


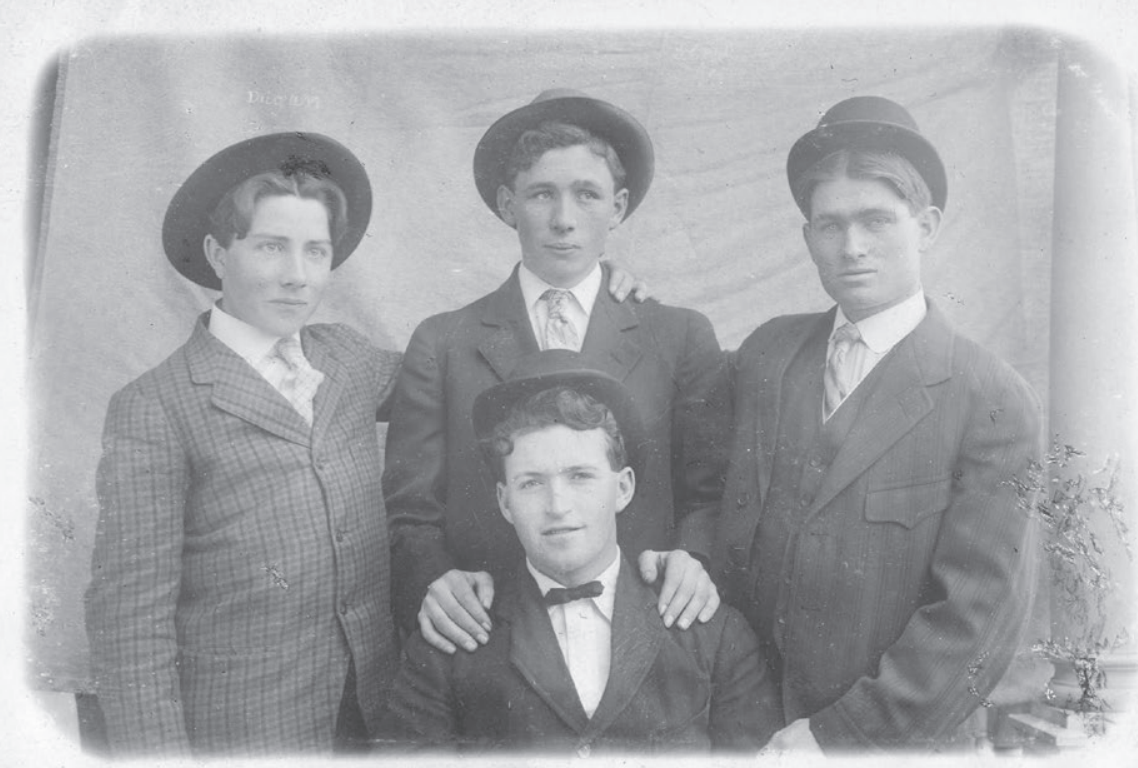

Slika 13: Prijatelji

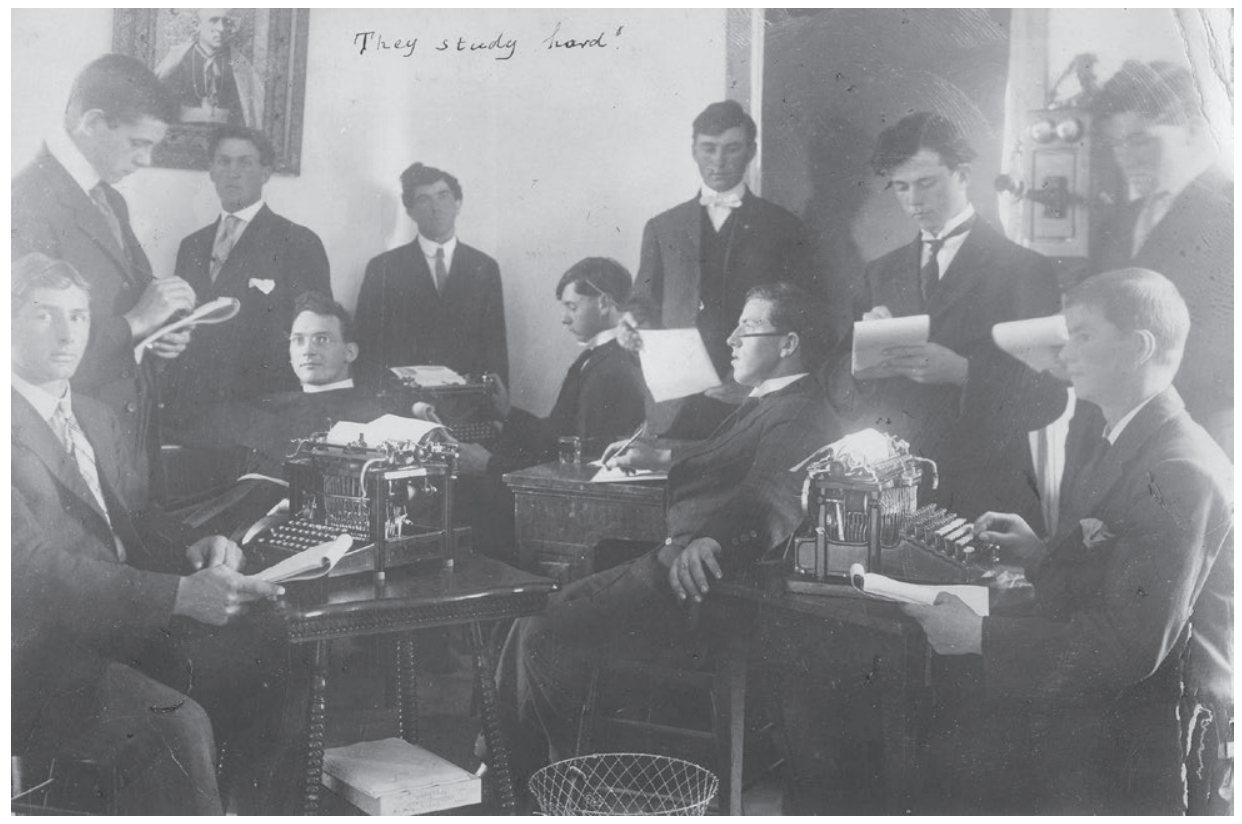

Slika 14: Studenti 


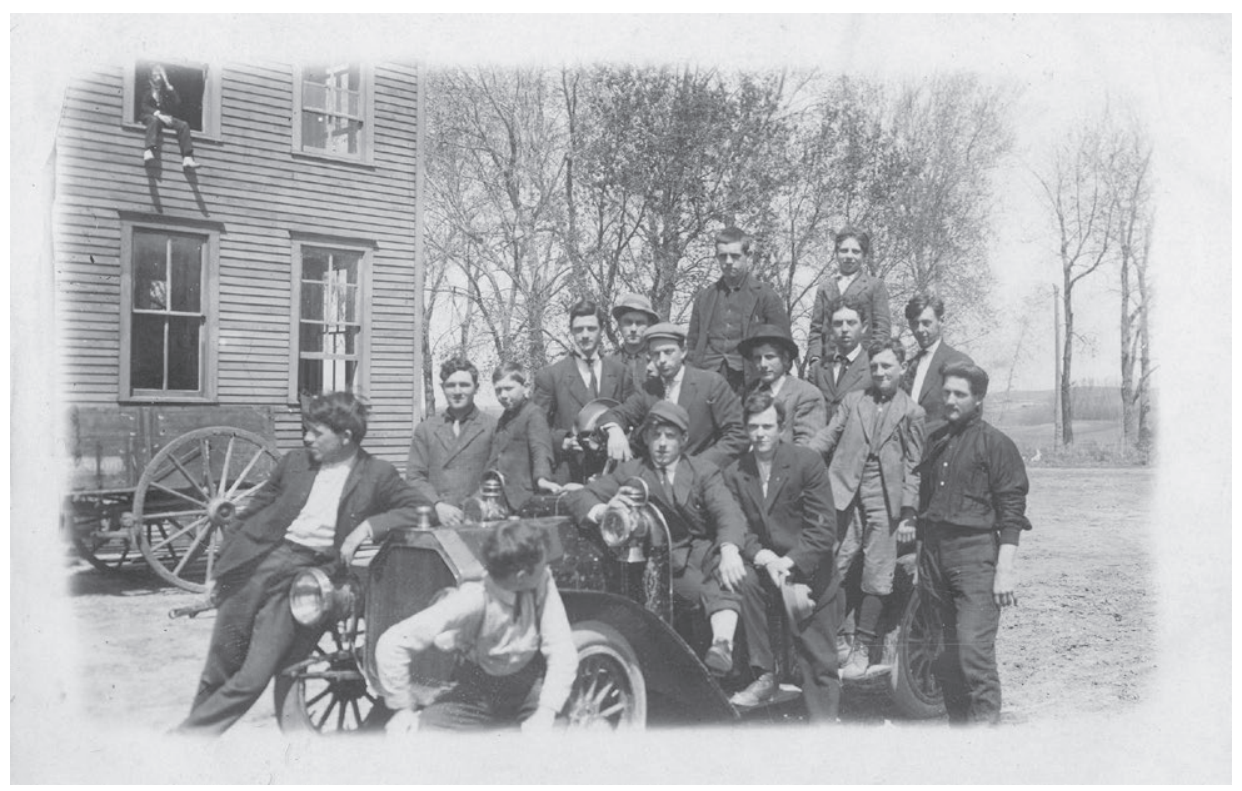

Slika 15: Na automobilu

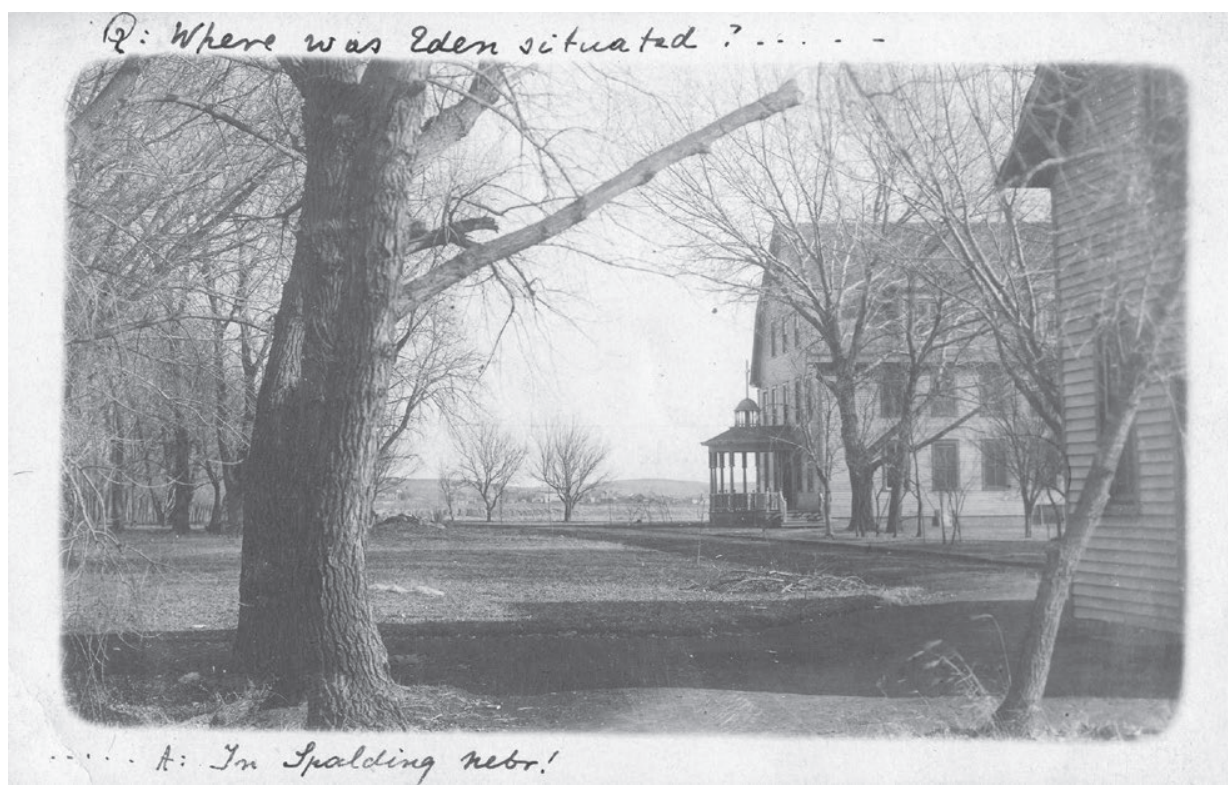

Slika 16: Where was Eden situated? 


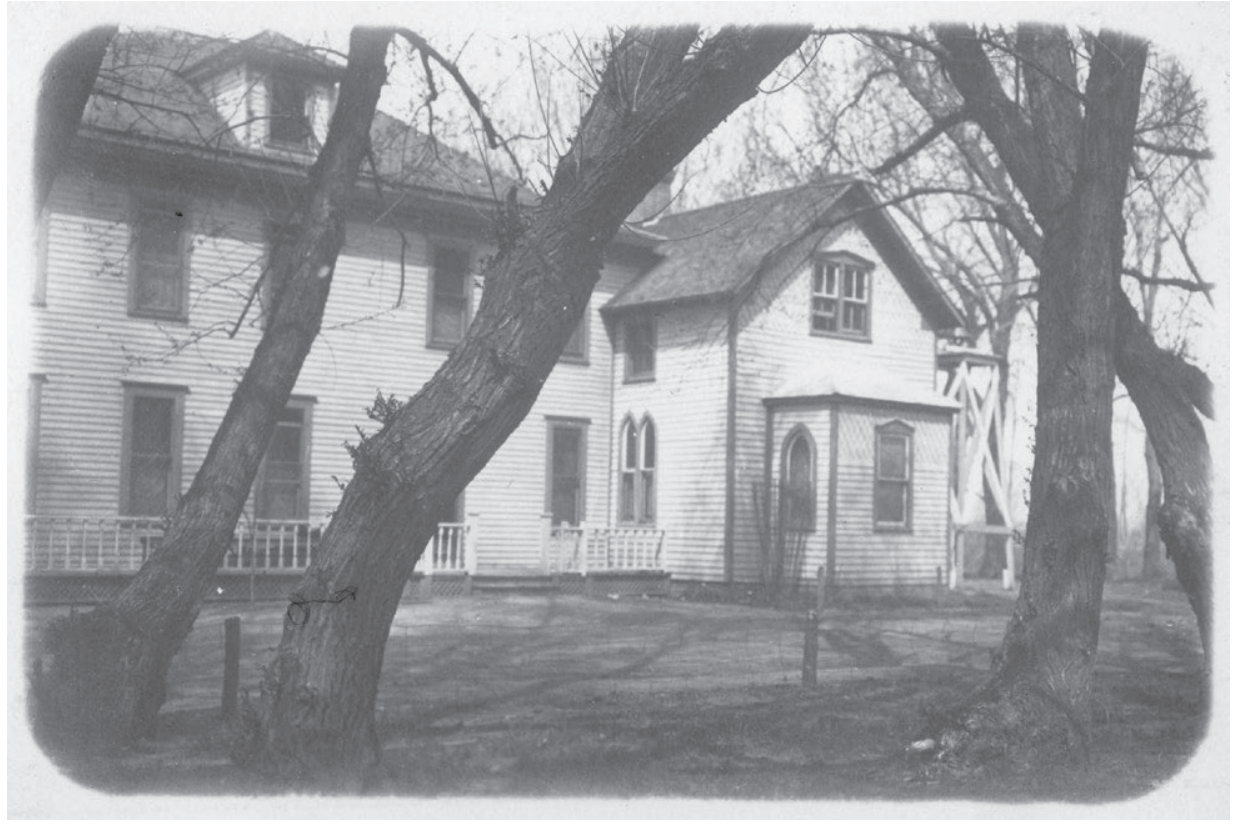

Slika 17: Spalding

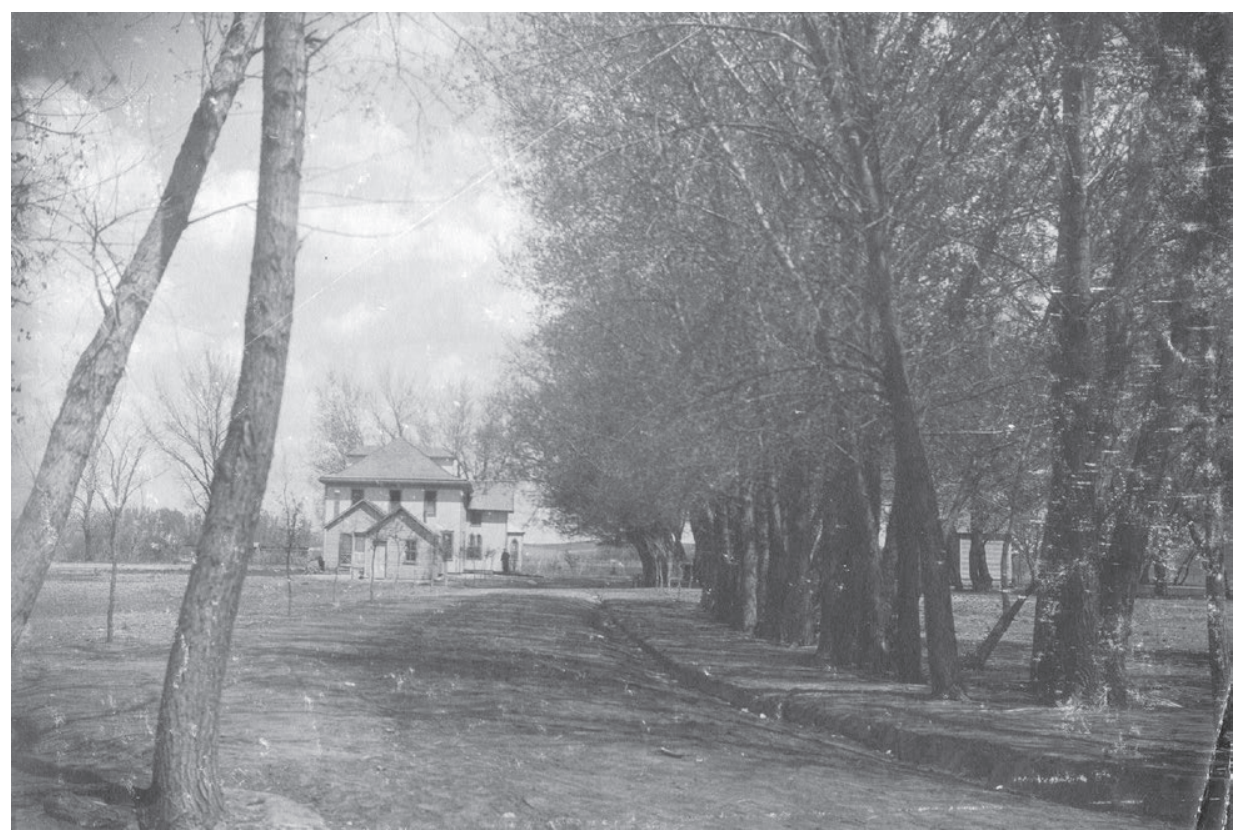

Slika 18: Spalding 2 


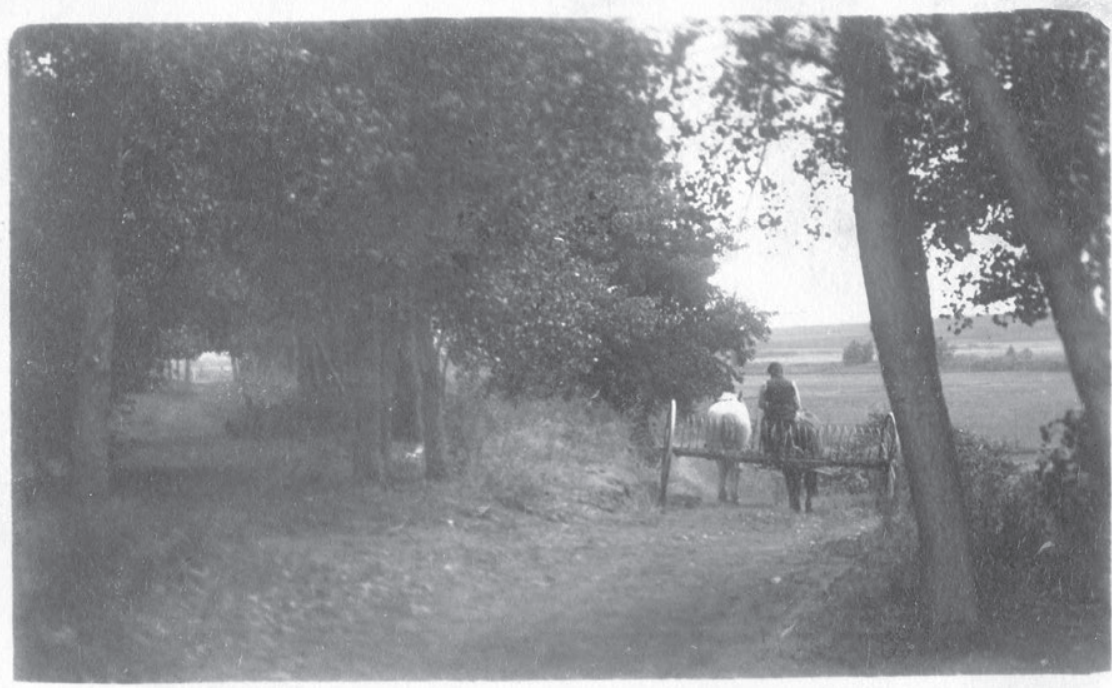

46. Leirize zacoda

Slika 19: U blizini Zavoda

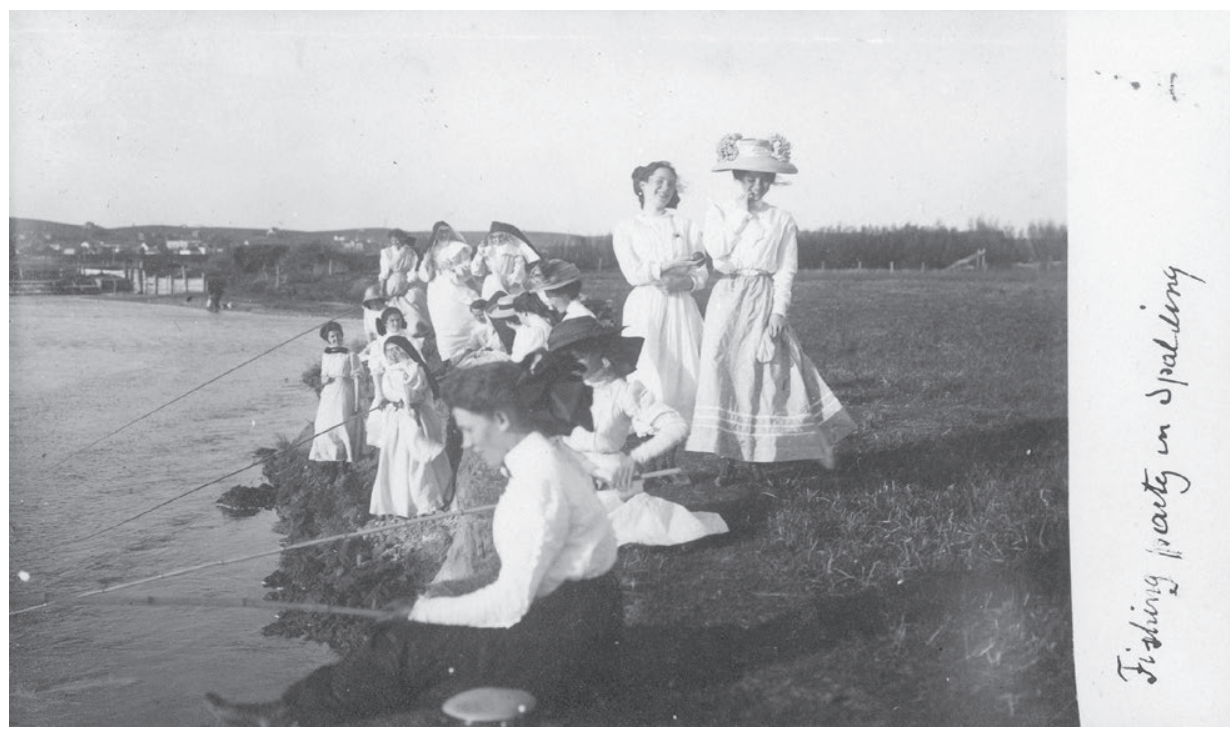

Slika 20: Fishing party 


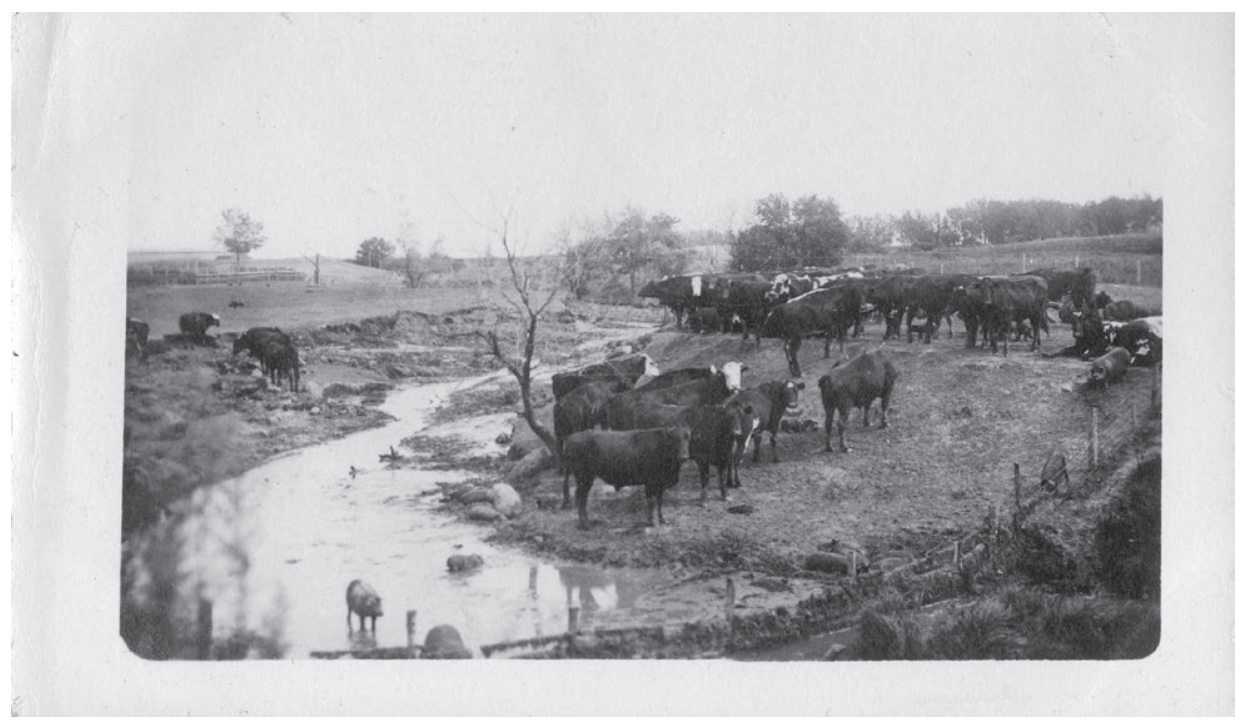

Slika 21: Goveda i svinje

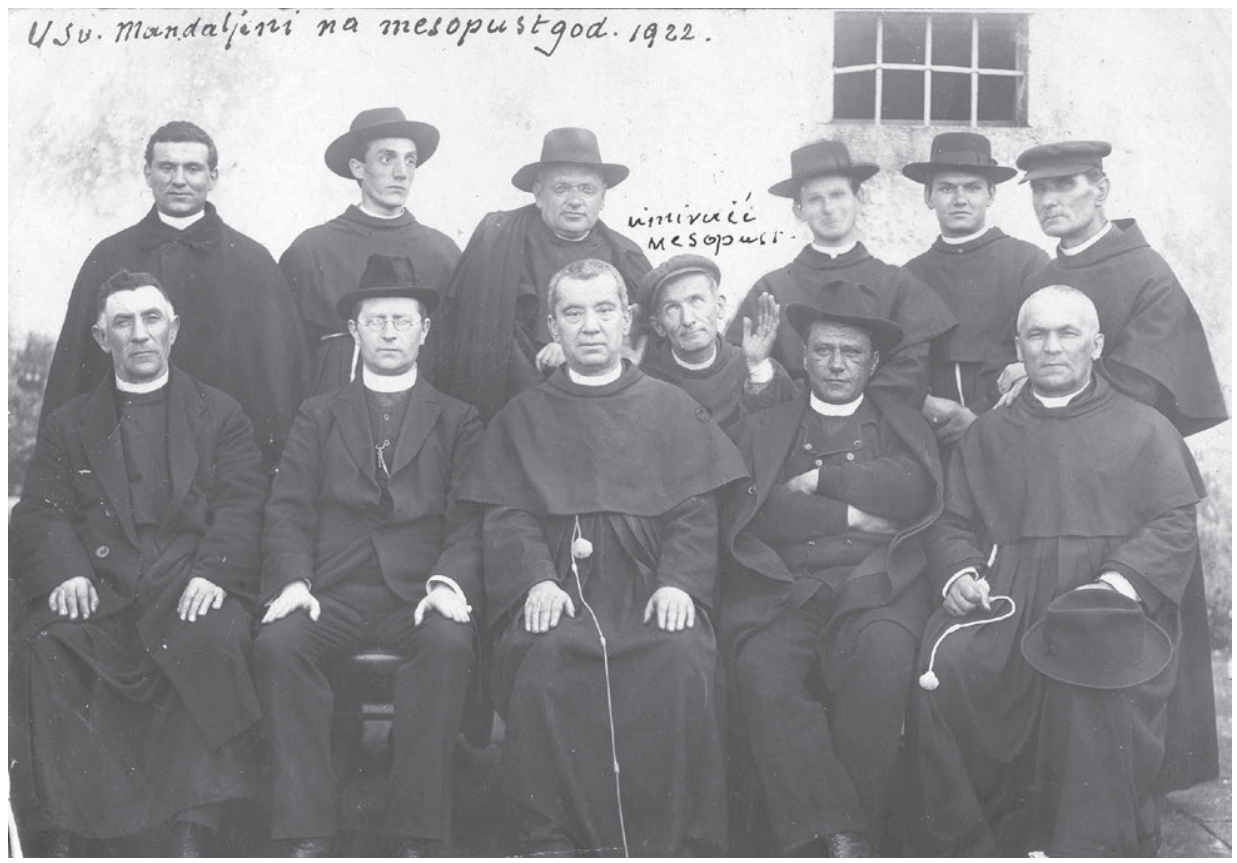

Slika 22: Porat, na mesopust 1922. 


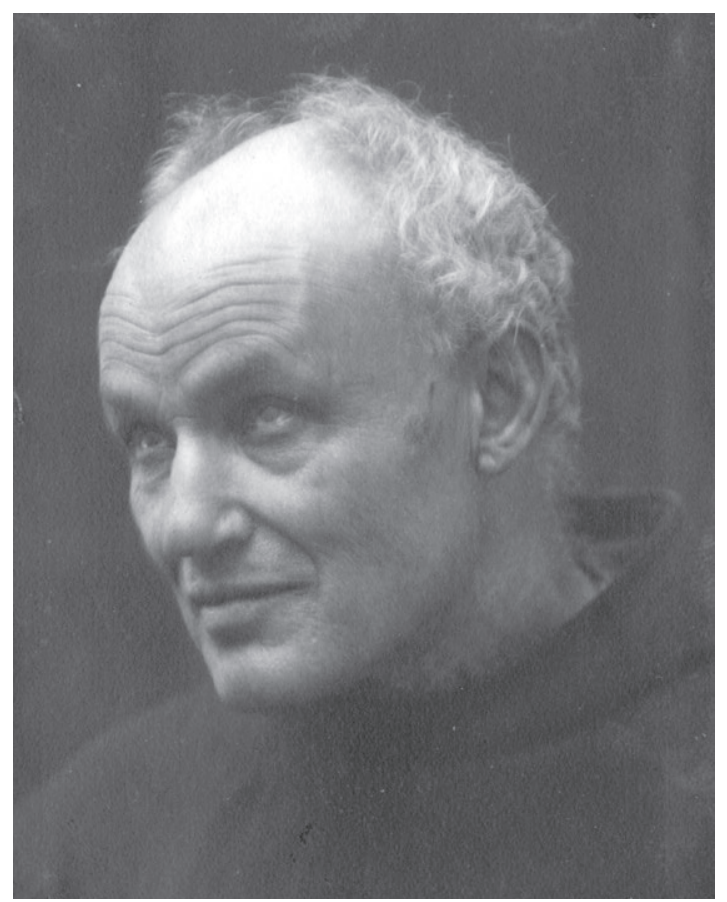

Slika 23: fra Josip Aršić

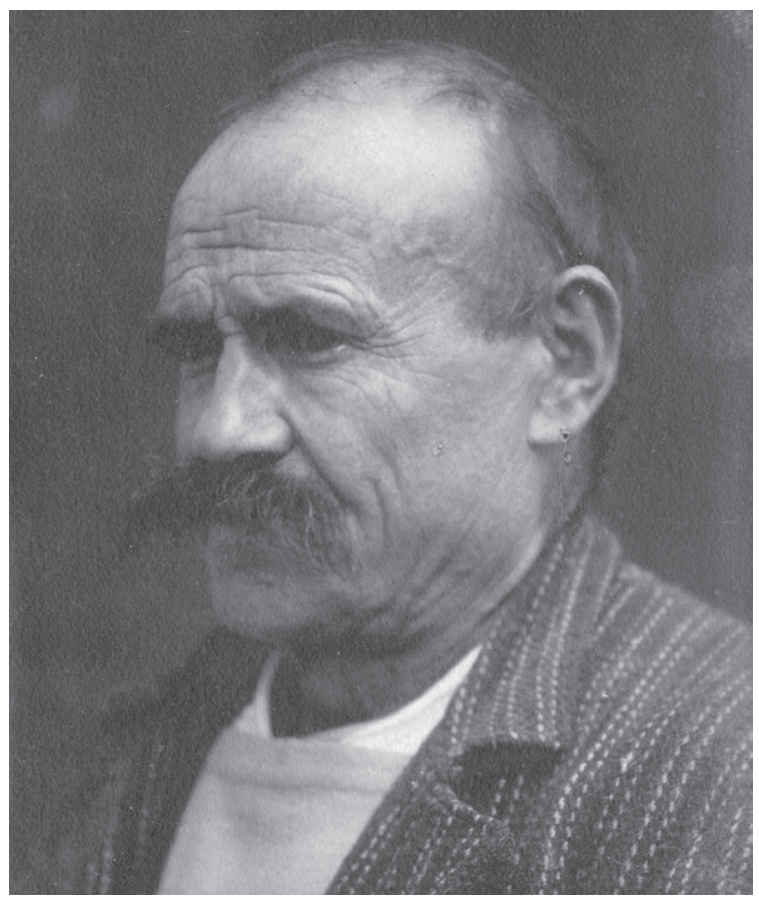

Slika 24: Božina Sorić 


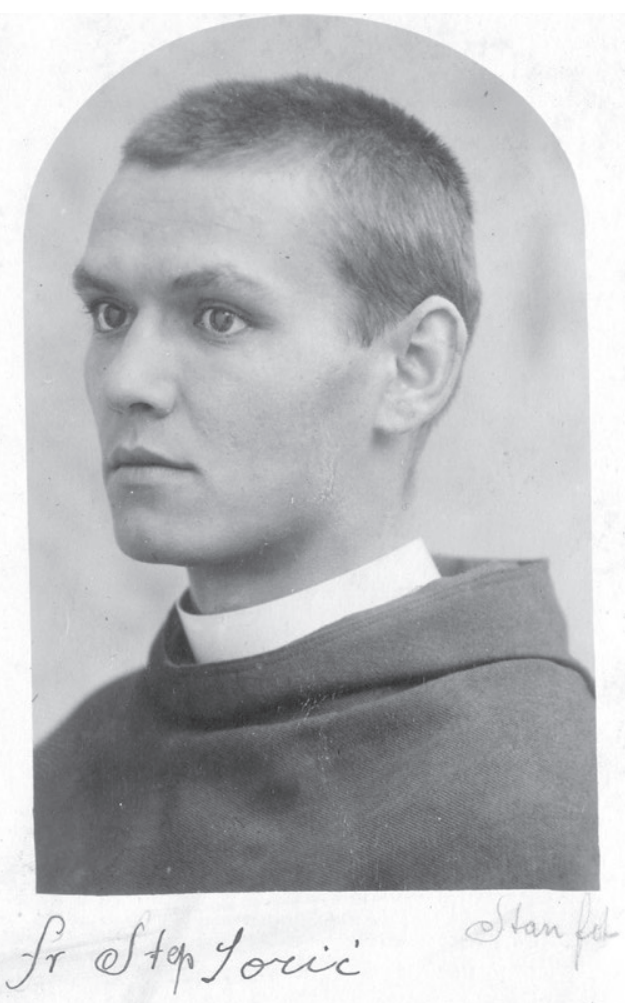

Slika 25: fra Stjepan Sorić

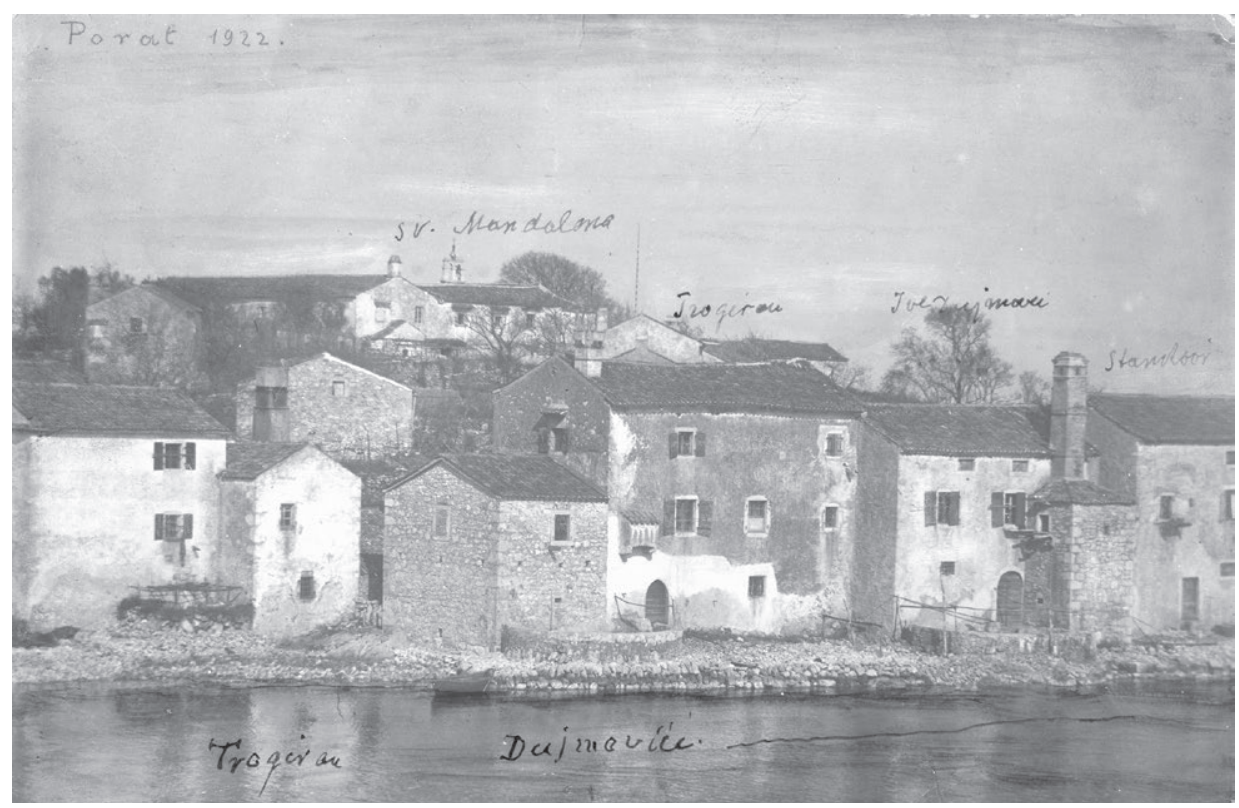

Slika 26: Porat 1922. 


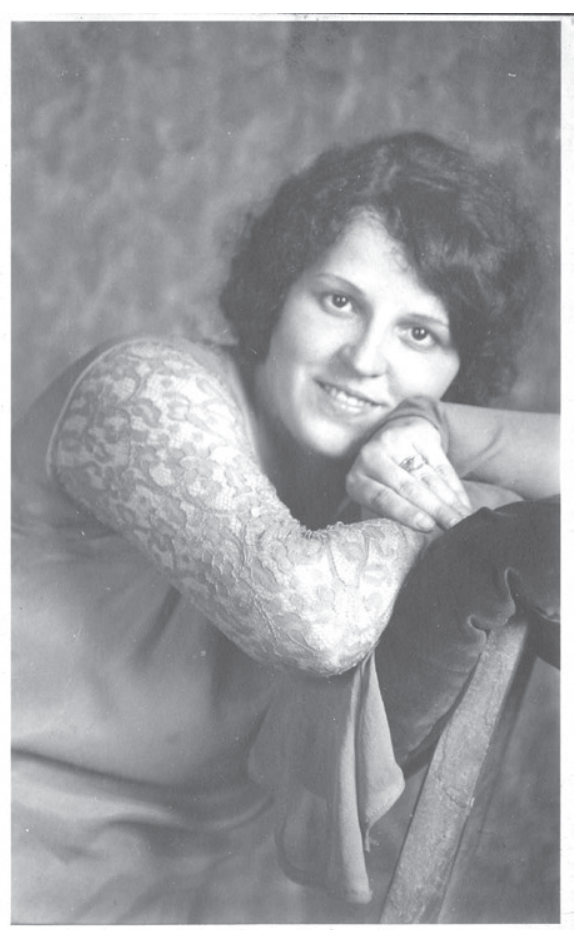

Hatica. Frrketic

Slika 27: Katica Frketić

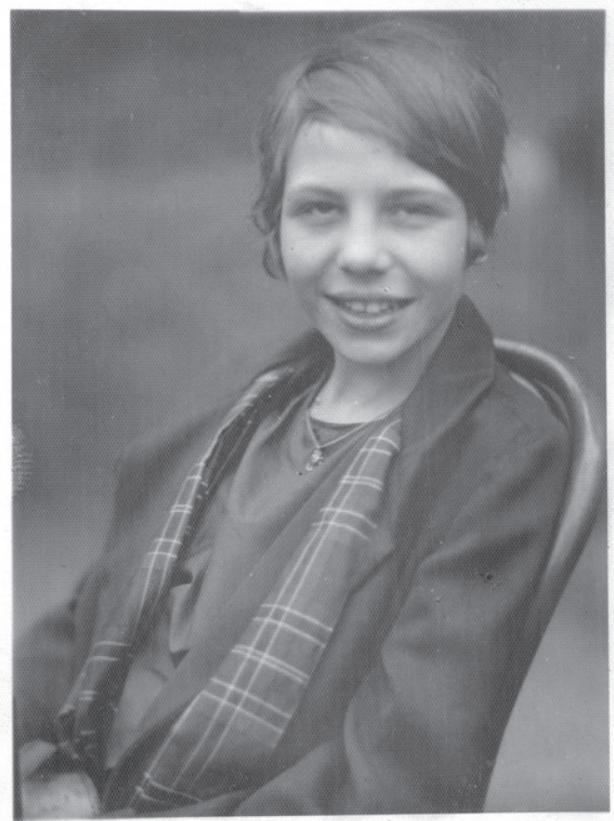

Slika 28: Portret-koloriran 


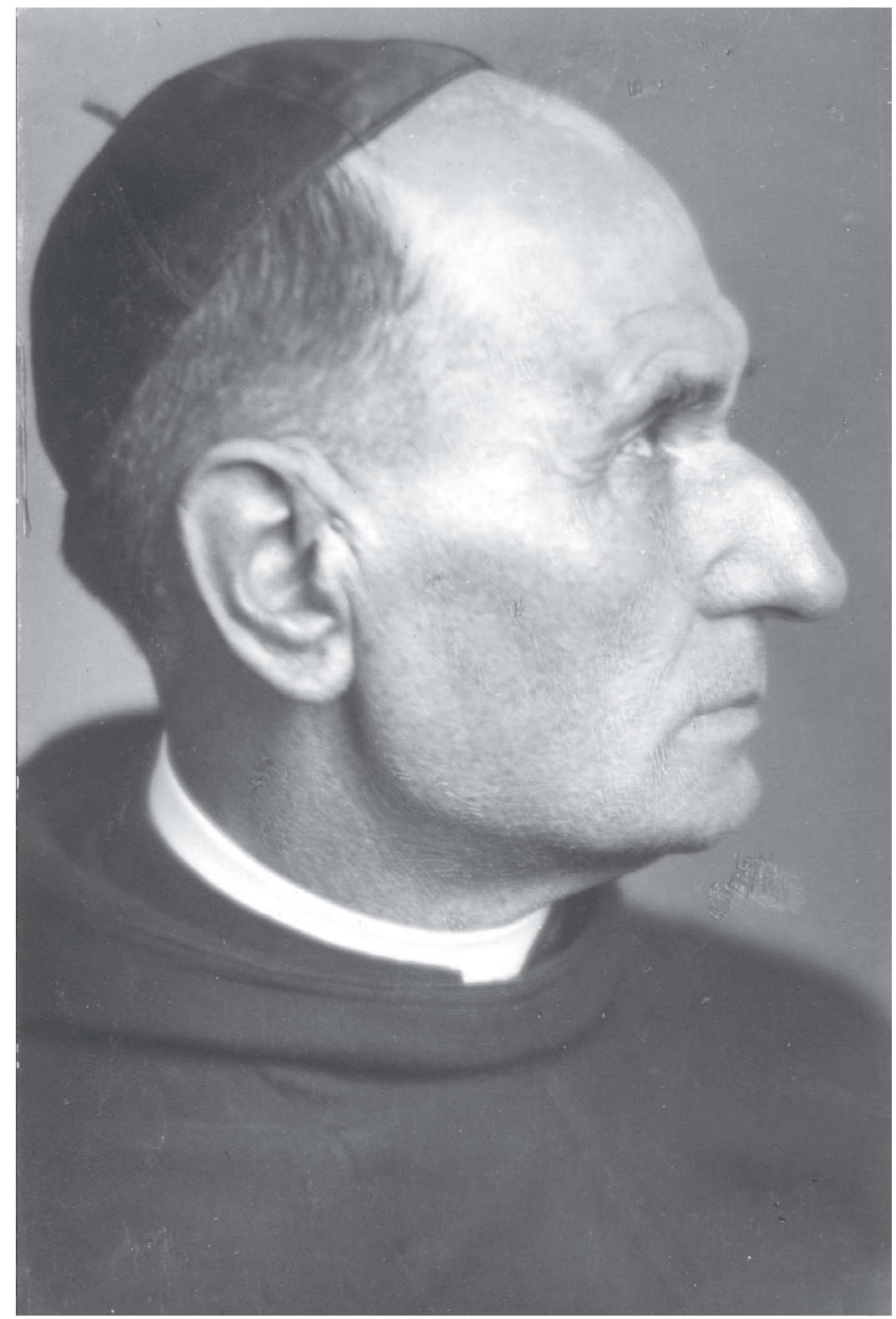

Slika 29: Autoportret s kalotom 


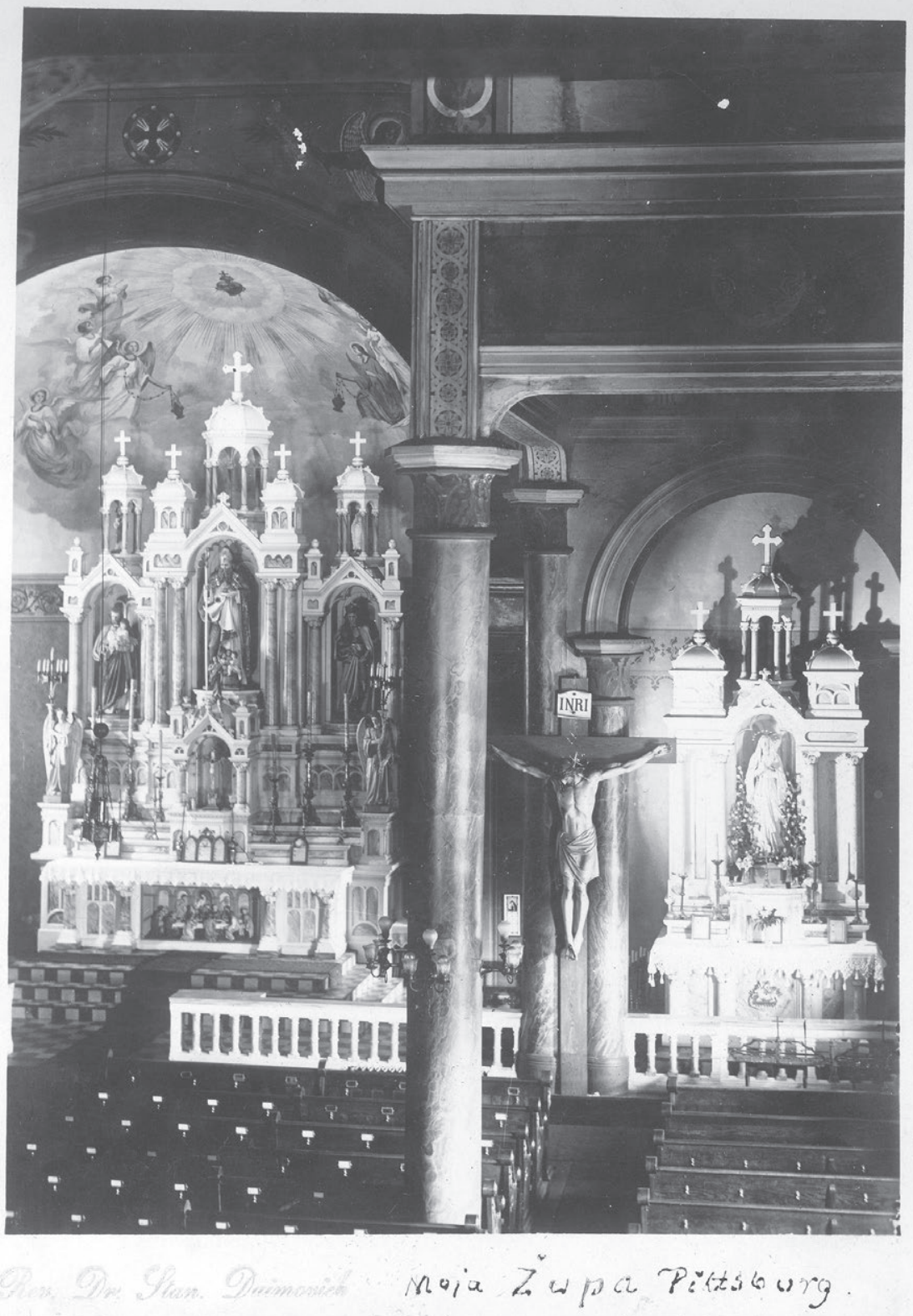

Slika 30: Krist 


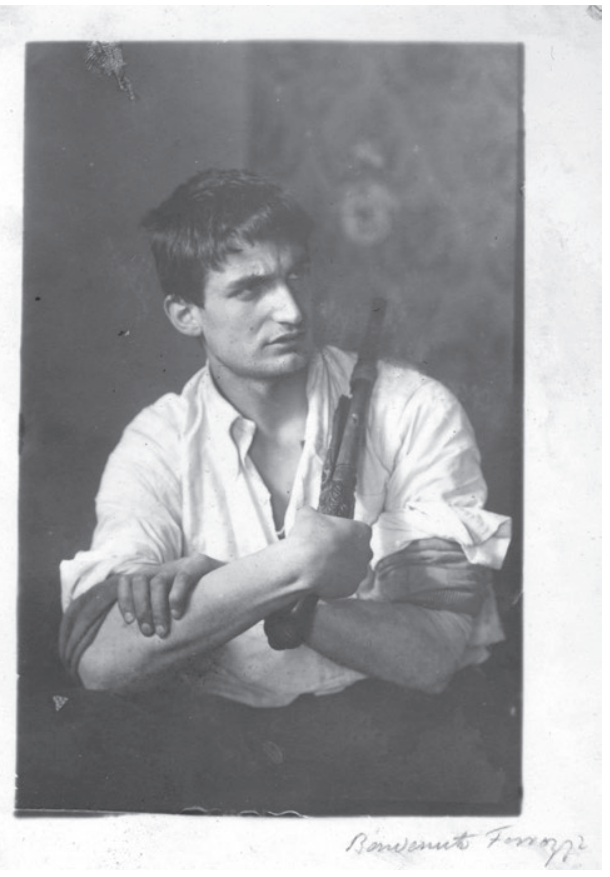

Slika 31: S kuburom

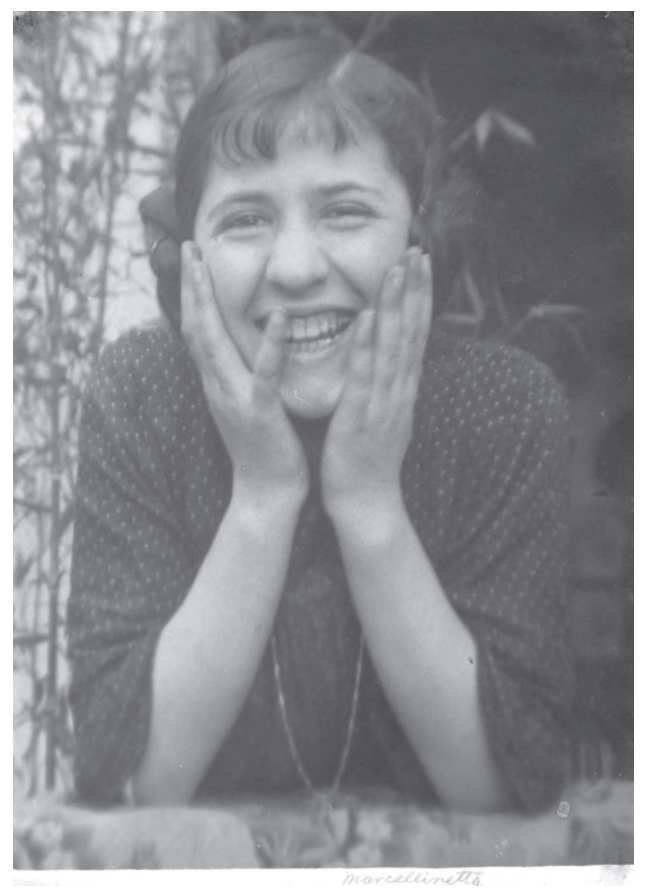

Slika 32: Marcellinetta 


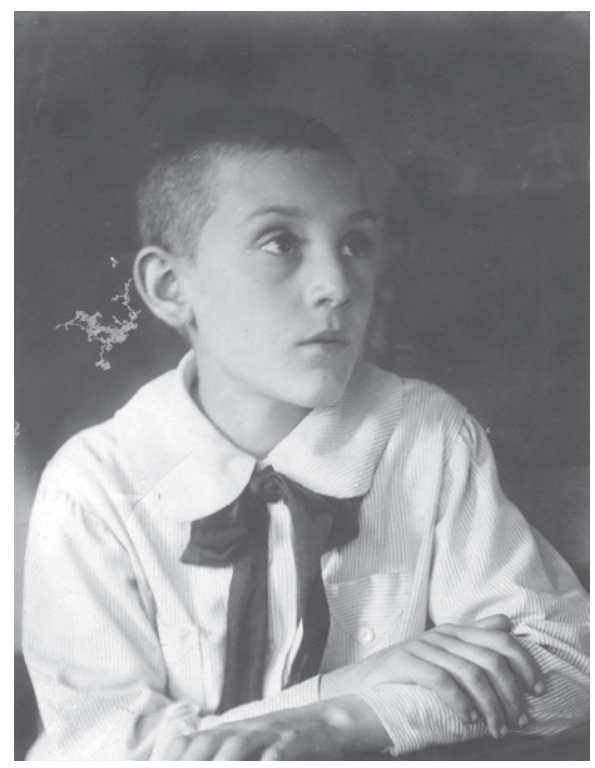

Slika 33: Portret dječaka

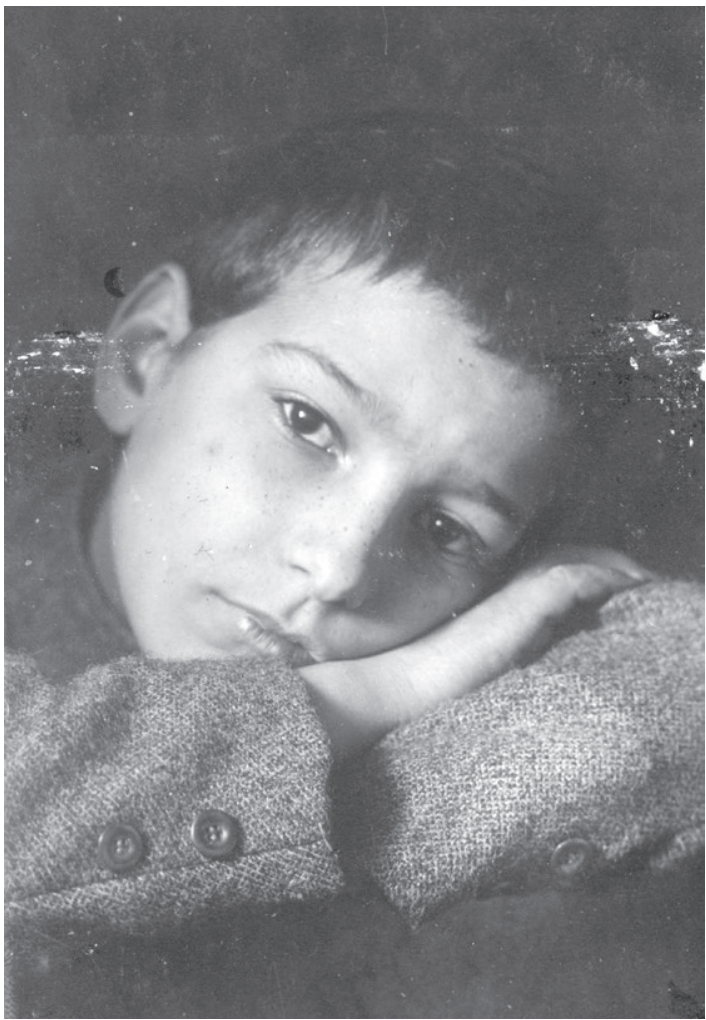

Slika 34: Portret dječaka 2 


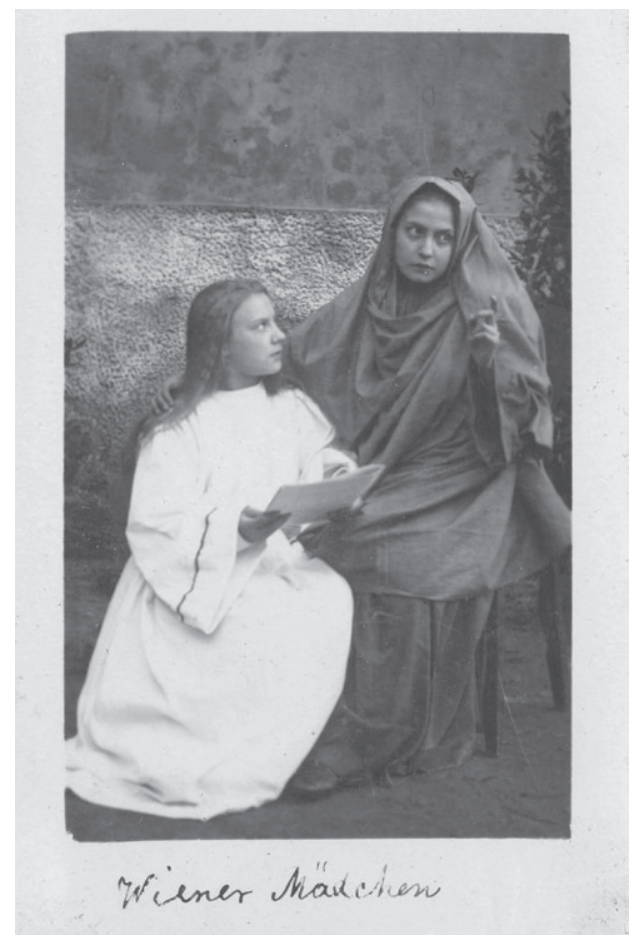

Slika 35: Wiener Mädchen

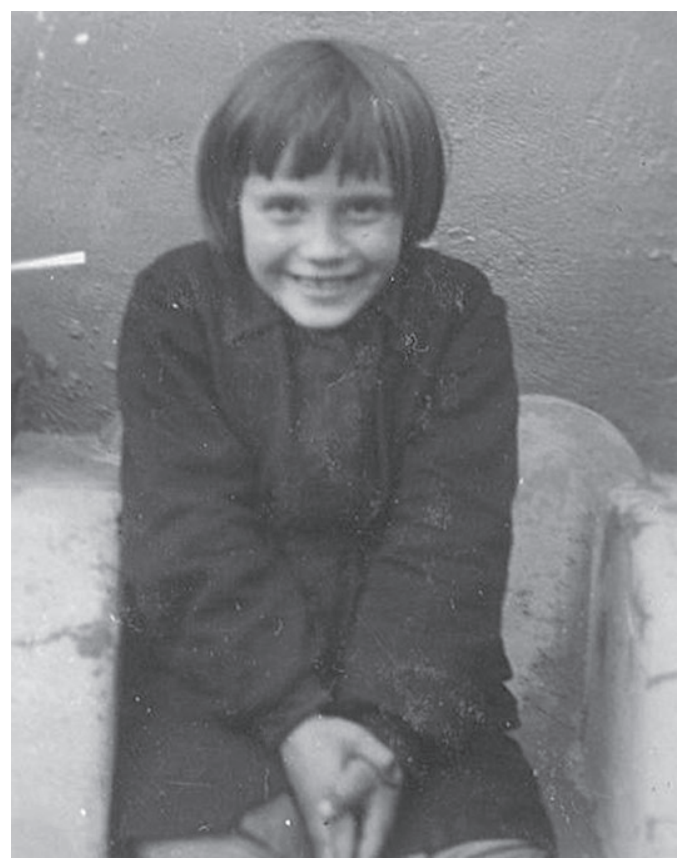

Slika 36: Portret djevojčice 


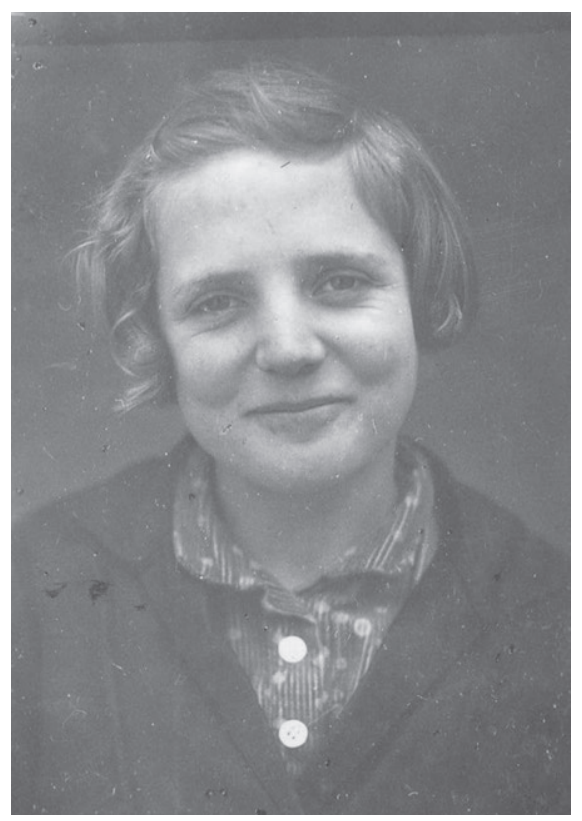

Slika 37: Portret djevojčice 2

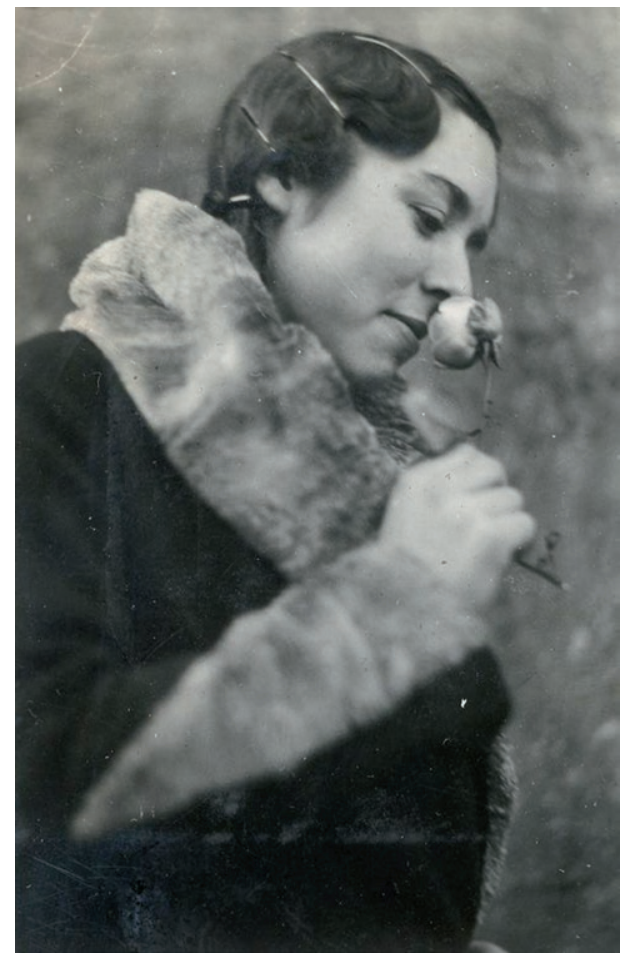

Slika 38: Djevojka s ružom 


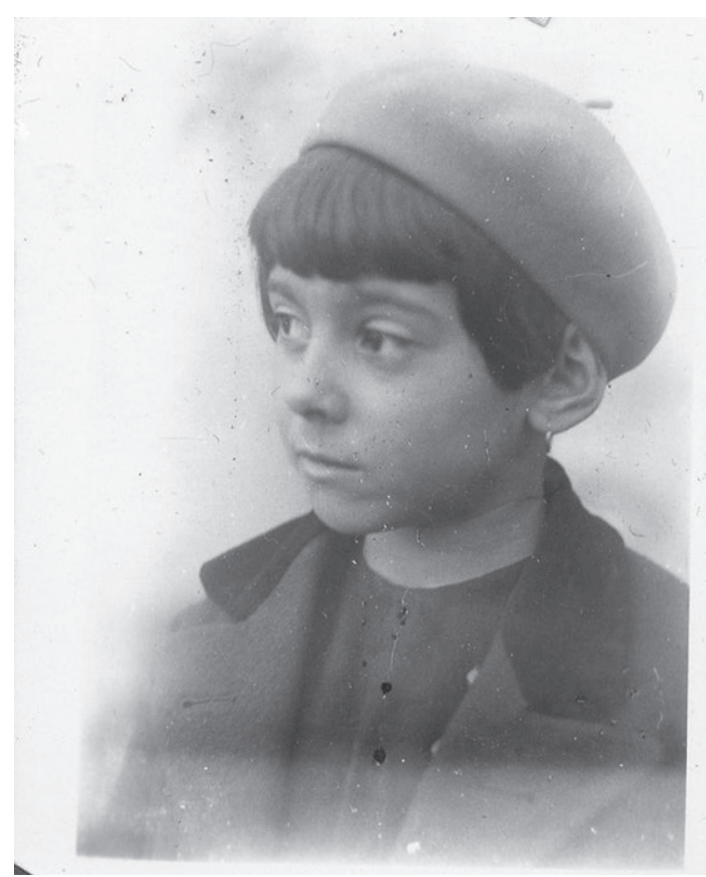

Slika 39: Portret djevojčice 3

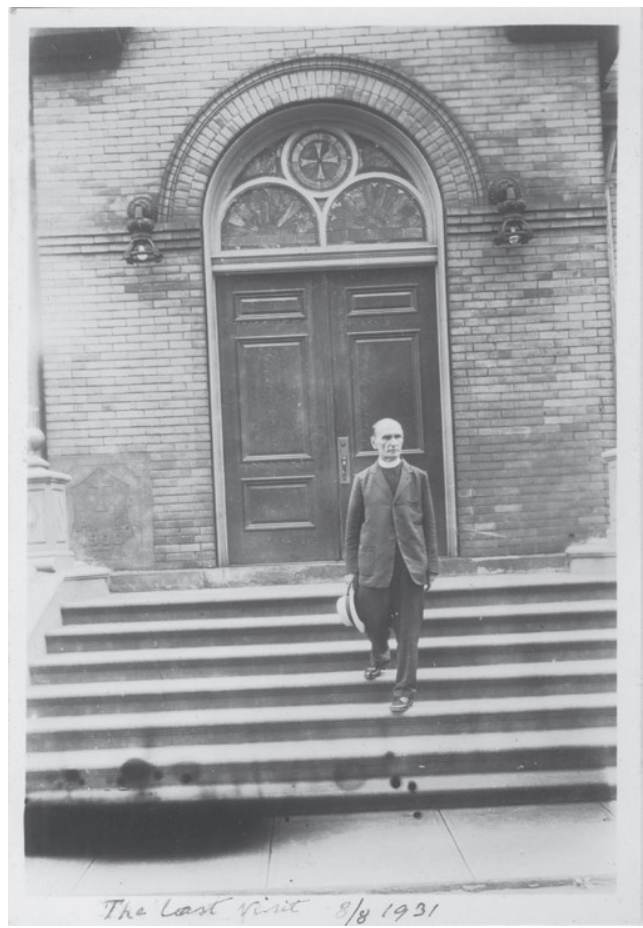

Slika 40: Last Visit 8.8.1931. 


\section{FILOZOFSKI FAKULTET SVEUČILIŠTA U ZAGREBU \\ ZAVOD ZA HRVATSKU POVIJEST \\ INSTITUTE OF CROATIAN HISTORY \\ INSTITUT FÜR KROATISCHE GESCHICHTE}

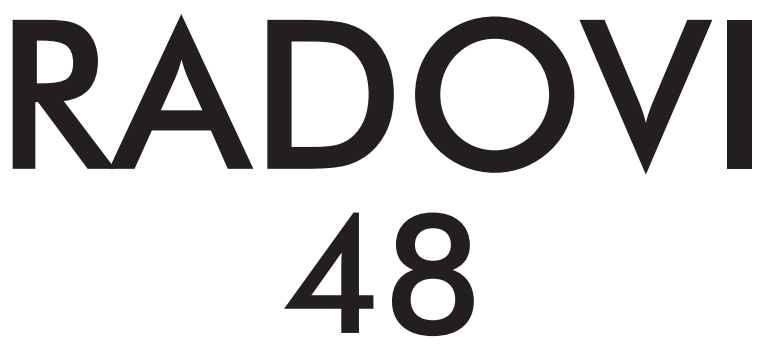

ZAVOD ZA HRVATSKU POVIJEST

FILOZOFSKOGA FAKULTETA SVEUČILIŠTA U ZAGREBU

\section{FF press}

ZAGREB 2016. 


\title{
RADOVI ZAVODA ZA HRVATSKU POVIJEST FILOZOFSKOGA FAKULTETA SVEUČILIŠTA U ZAGREBU \\ Knjiga 48
}

\author{
Izdavač / Publisher \\ Zavod za hrvatsku povijest \\ Filozofskoga fakulteta Sveučilišta u Zagrebu \\ FF-press \\ Za izdavača / For Publisher \\ Željko Holjevac \\ Glavni urednik / Editor-in-Chief \\ Hrvoje Gračanin \\ Izvršna urednica / Executive Editor \\ Inga Vilogorac Brčić \\ Uredništvo / Editorial Board
}

Bruna Kuntić-Makvić (stara povijest/ancient history), Zrinka Nikolić Jakus (srednji vijek/ medieval history), Hrvoje Petrić (rani novi vijek/early modern history), Željko Holjevac (moderna povijest/modern history), Tvrtko Jakovina (suvremena povijest/contemporary history),

Silvija Pisk (mikrohistorija i zavičajna povijest/microhistory and local history),

Zrinka Blažević (teorija i metodologija povijesti/theory and methodology of history)

Međunarodno uredničko vijeće / International Editorial Council

Denis Alimov (Sankt Peterburg), Živko Andrijašević (Nikšić), Csaba Békés (Budapest), Rajko Bratož (Ljubljana), Snježana Buzov (Columbus, Ohio), Svetlozar Eldarov (Sofija), Toni Filiposki (Skopje), Aleksandar Fotić (Beograd), Vladan Gavrilović (Novi Sad), Alojz Ivanišević (Wien),

Egidio Ivetić (Padova), Husnija Kamberović (Sarajevo), Karl Kaser (Graz),

Irina Ognyanova (Sofija), Géza Pálffy (Budapest), Ioan-Aurel Pop (Cluj),

Nade Proeva (Skopje), Alexios Savvides (Kalamata), Vlada Stanković (Beograd), Ludwig Steindorff (Kiel), Peter Štih (Ljubljana)

\section{Izvršna urednica za tuzemnu i inozemnu razmjenu / Executive Editor for Publications Exchange \\ Kristina Milković}

Tajnik uredništva / Editorial Board Assistant
Dejan Zadro

Adresa uredništva/Editorial Board address

Zavod za hrvatsku povijest, Filozofski fakultet Zagreb, Ivana Lučića 3, HR-10 000, Zagreb

Tel. ++385 (0)1 6120 150, 6120 158, faks ++385 (0)1 6156879

Časopis izlazi jedanput godišnje / The Journal is published once a year

Časopis je u digitalnom obliku dostupan na / The Journal in digital form is accessible at Portal znanstvenih časopisa Republike Hrvatske „Hrčak“ http://hrcak.srce.hr/radovi-zhp

Financijska potpora za tisak časopisa / The Journal is published with the support by

Ministarstvo znanosti, obrazovanja i športa Republike Hrvatske

Časopis je indeksiran u sljedećim bazama / The Journal is indexed in the following databases:

Directory of Open Access Journals, EBSCO, SCOPUS, ERIH PLUS, Emerging Sources Citation Index - Web of Science 


\section{Naslovna stranica}

Iva Mandić

Grafičko oblikovanje i računalni slog

Marko Maraković

\section{Lektura}

Samanta Paronić (hrvatski / Croatian)

Dražen Nemet (engleski / English)

Tisak

Tiskara Zelina d.d., Sveti Ivan Zelina

Naklada

250 primjeraka

Časopis je u digitalnom obliku dostupan na Portalu znanstvenih časopisa Republike Hrvatske ,Hrčak" http://hrcak.srce.hr/radovi-zhp

The Journal is accessible in digital form at the Hrcak - Portal of scientific journals of Croatia http://hrcak.srce.hr/radovi-zhp 


\section{RADOVI 48}

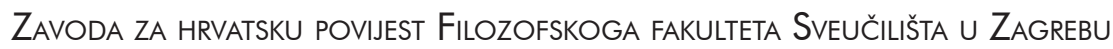

